\title{
Extraction and Nano-Sized Delivery Systems for Phlorotannins to Improve Its Bioavailability and Bioactivity
}

\author{
Tianjian Tong ${ }^{2}$, Xiaoyang Liu ${ }^{1, *(1)}$ and Chenxu $\mathrm{Yu}^{2, *}$ \\ 1 National Engineering Research Center for Seafood, Dalian Polytechnic University, Dalian 116034, China \\ 2 Department of Agricultural and Biosystems Engineering, Iowa State University, Ames, IA 50011, USA; \\ tianjian@iastate.edu \\ * Correspondence: liuxiaoyang0213@126.com (X.L.); chenxuyu@iastate.edu (C.Y.)
}

Citation: Tong, T.; Liu, X.; Yu, C. Extraction and Nano-Sized Delivery Systems for Phlorotannins to Improve Its Bioavailability and Bioactivity. Mar. Drugs 2021, 19, 625. https:// doi.org/10.3390/md19110625

Academic Editors: María

Carmen Rodríguez-Argüelles and Rosana Simón-Vázquez

Received: 29 September 2021

Accepted: 28 October 2021

Published: 5 November 2021

Publisher's Note: MDPI stays neutral with regard to jurisdictional claims in published maps and institutional affiliations.

Copyright: (c) 2021 by the authors. Licensee MDPI, Basel, Switzerland. This article is an open access article distributed under the terms and conditions of the Creative Commons Attribution (CC BY) license (https:// creativecommons.org/licenses/by/ $4.0 /)$.

\begin{abstract}
This review aims to provide an informative summary of studies on extraction and nanoencapsulation of phlorotannins to improve their bioavailability and bioactivity. The origin, structure, and different types of phlorotannins were briefly discussed, and the extraction/purification/ characterization methods for phlorotannins were reviewed, with a focus on techniques to improve the bioactivities and bioavailability of phlorotannins via nano-sized delivery systems. Phlorotannins are promising natural polyphenol compounds that have displayed high bioactivities in several areas: anticancer, anti-inflammation, anti-HIV, antidiabetic, and antioxidant. This review aims to provide a useful reference for researchers working on developing better utilization strategies for phlorotannins as pharmaceuticals, therapeuticals, and functional food supplements.
\end{abstract}

Keywords: phlorotannins; nano delivery systems; bioavailability; bioactivity

\section{Introduction}

Phlorotannins are a large group of chemical compounds found in brown algae (kelp, rockweeds, etc.), accounting for about $5-12 \%$ of the dry mass [1]. Phlorotannins have attracted substantial attention from the research community due to their high bioactivities [2-12], which could be utilized in various medical and nutritional enhancement applications $[5,6]$. Phlorotannins are natural compounds with low toxicity compared to man-made compounds $[13,14]$, which has added to their appeal.

Phlorotannins are tannins exist primarily in brown algae $[1,15]$. Phlorotannin content in seaweeds can also vary for individual species, geographic regions, and extraction techniques [16]. They are developed from phloroglucinol (1,3,5-trihydroxybenzene) via acetate-malonate (polyketide) pathway which are different from other hydrolysable and condensed tannins [14,17], with molecular weight ranging from 126 to $1 \times 100 \mathrm{KDa}$ [18-22]. The structural differences among phlorotannins are widely recognized. There are six different types (i.e., classes) of phlorotannins: fucols, fucophlorethols, fuhalols, carmalols, phlorethols, and eckols, as listed in Table 1 [19-23]. Inside each class, phloroglucinol (1,3,5trihydroxybenzene) monomers can bind to one another at different locations of the ring of phloroglucinol [17]. These free bindings lead to all kinds of isomer structures in addition to the conformational ones [17]. From another perspective, we can re-group phlorotannins into two basic groups: linear phlorotannin and branched phlorotannin [17], with linear phlorotannin having two terminal phloroglucinol monomer residues and branched phlorotannin having three terminal phloroglucinol monomer residues. 
Table 1. Six basic types of phlorotannin in brown algae.

\begin{tabular}{|c|c|c|}
\hline Type of Phlorotannin & Basic Linkage & Representative Structural Formula \\
\hline Fucols & aryl-aryl linkages & \\
\hline Fucophlorethols & aryl-aryl and aryl-ether & \\
\hline Fuhalols & aryl-ether linkages, $\mathrm{OH}$ groups in every third ring & \\
\hline Carmalols & dibenzodioxin linkages & \\
\hline Phlorethols & aryl-ether linkages & \\
\hline Eckols & $\begin{array}{l}\text { a dibenzodioxin element substituted by a } \\
\text { phenoxyl group at } C-4\end{array}$ & \\
\hline
\end{tabular}

The composition, amount, and types of phlorotannins obtained from seaweed such as brown algae could be dependent on the extraction techniques used. Traditionally, phlorotannin are isolated via organic solvent extraction followed by chromatographic techniques to purify the compounds [24-26]. More recently, hot-pressurized liquid extraction (HPLE) [2,27-32] and integrated process of HPLE-resin purification (HPLE-RP) have also been developed $[33,34]$, which produced higher phenolic compound yields than traditional methods. Typical liquid extraction (LE) involves using one polar solvent (water in most cases) and one non-polar solvent [35-37], and phlorotannins transfer from the polar solvent to the non-polar one with chemical potential being the driving force of this transfer [35-37]. Most conventional LE methods have in common "cons" of being "non-green" due to usage of organic solvents [34]. In a recent effort, in which boiling water was used instead of "nongreen" solvent as the extraction solvent, Chowdhury et al. [38] reported a recovery yield of dieckol from E. cava, E. stolonifera, and E. bicyclis to be $86 \%, 93 \%$, and $98 \%$, respectively. More detailed discussion on extraction methods can be found in Section 2 below.

Phlorotannins have been shown to have anti-inflammatory, anti-HIV, anticancer, antidiabetic, and antioxidant functionalities. Phlorotannins are effective regulators of 
several biochemical processes linked to the disruption of homeostasis in major chronic diseases [18,39]. Inflammation is part of the process by which the immune system defends the body from harmful agents, such as bacteria and viruses [40-43]. Phlorotannins isolated from different brown algae demonstrated anti-inflammatory bioactivity in many cases: phlorotannin isolated from E. cava can suppress oxidative stress and inflammatory mediators [44], and phlorotannin isolated from E. stolonifera can suppress iNOS and expression of COX-2 gene [45], to name a few examples. Phlorotannin was also reported to have anti-HIV activities [11]. 6,6'-bieckol isolated from E. cava can suppress HIV-1-induced syncytia formation and production of viral p24 antigen [11]. Phlorotannins were also shown have anticancer bioactivity [12,46]: eckol can suppress tumor growth in vivo on S180 xenograft-bearing mice [46]. They were also reported to have antidiabetic qualities [47-54] by suppressing $\alpha$-glucosidase, PTP 1B, aldose reductase, ACE, AGEs, and aldose reductase [47-54]. To be more specific, dioxinodehydroeckol can suppress $\alpha$-glucosidase and PTP 1B [47]; 7-phloroeckol can suppress $\alpha$-glucosidase and PTP 1B [47]; dieckol can suppress $\alpha$-glucosidase [53]; and 7-phloroeckol can suppress ACE and $\alpha$-glucosidase [53].

Last by not least, phlorotannins are strong natural antioxidants [55-60]. Dieckol can suppress UV-B radiation induced photo-oxidative stress in human fibroblast cell line and reduce cell damage [55]; diphlorethohydroxycarmalol (DPHC) isolated from I. okamurae can scavenge UV-B radiation induced ROS in human fibroblast cells [57]; and dieckol can reduce cell damage induced by UV-B radiation both in vitro (HaCaT cells) [61] and in vivo (zebra fish) [59]. Phlorotannins can also potentially be used as functional ingredients in skin care products to offer protection against photo-induced skin damages.

Although phlorotannins have many attractive biofunctionalities, as members of the polyphenol family, phlorotannins also suffer from low bioavailability, which limits their utilization. Polyphenols' low bioavailability is mainly due to their low absorption in the human gastrointestinal (GI) tract following consumption and their extensive biotransformation within the gut, which may lead to their rapid clearance from the body (Figure 1 [62]). To improve the bioavailability of phlorotannins, nano-sized delivery systems have been investigated [26,61,63-70]. Figure 2 showed a schematic representation of examples of these systems [71]. These nano-enabled approaches could protect phlorotannins against transformation in the gut; they can also improve delivery/absorption of phlorotannins [61]. Nano-phlorotannin systems were also shown to enhance the functionality of the phlorotannins. For example, gold nanoparticle-phlorotannin and silver nanoparticle-phlorotannin complexes have been investigated by serval researchers [26,61,63-70]; they were shown by DPPH assays to have elevated antioxidant activity. Nano-enabled improvement on bioavailability and bioactivity may offer a more effective way for the utilization of phlorotannins in pharmaceutical, food, and biochemical industries.

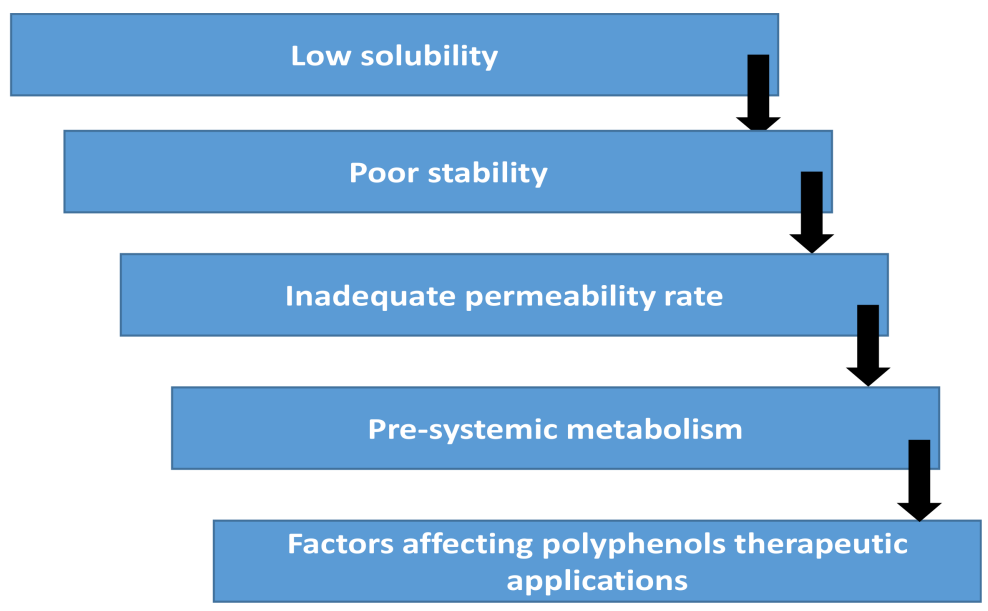

Figure 1. Factors affecting polyphenols therapeutic applications, replicated from Conte et al. [65] with permission. 


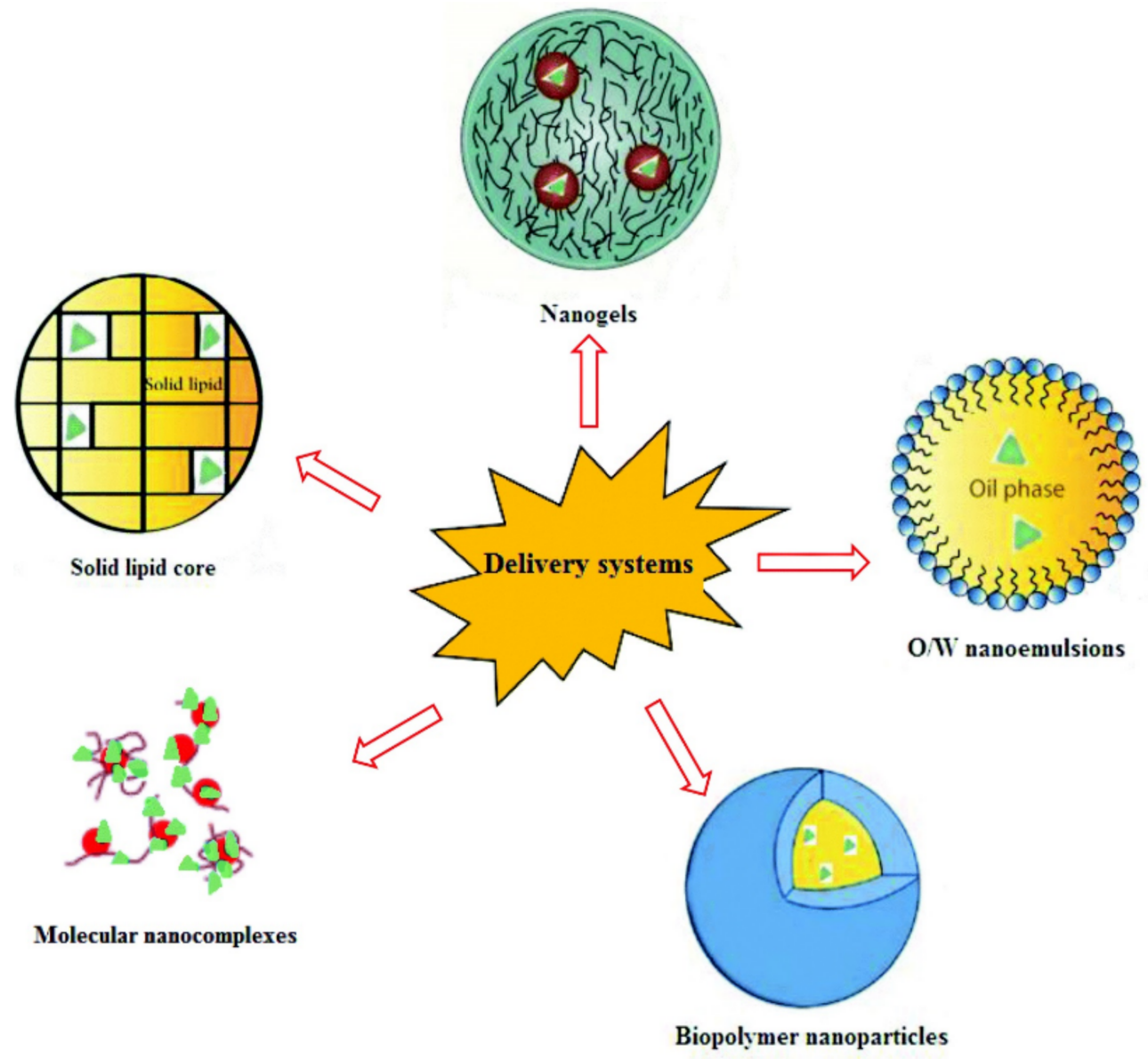

Figure 2. Schematic representation of nano-sized delivery systems, replicated from Qi et al. [71] with permission.

\section{Extraction and Purification of Phlorotannins}

The operation of phlorotannin extraction aims to achieve two major goals: one is to extract as high a quantity of phlorotannins, primarily from brown algae, as possible; another is to maintain high bio-integrity and bioactivities of the phlorotannins [7-12]. These two goals could be in conflict: phlorotannins are unstable polyhydroxylated molecules, and they can easily be oxidized [17]. Considering the different types of phlorotannins and their susceptibility to various physical/chemical processing, development of different isolation/extraction methods suitable for different types with specific biofunctionality [17] remains a challenge $[18,19]$. A quick summary of the pros and cons of common isolation/extraction methods reported by different research groups follows.

HPLE methods: HPLE is generally considered environmentally friendly to an extent, if water is used instead of organic solvents $[2,27,29,31,32]$. Low cost is another advantage of HPLE $[28,30]$. HPLE can also be scaled up to a certain extent to go beyond lab scale, but its yield as of today is still not high [29]. Another restriction of HPLE is that it requires the solvent to be kept in liquid state during the entire extraction process, which can be an operational challenge [29]. In addition, macroalgae might contain heavy metal [72], which could be extracted together with phlorotannins by HPLE [72] and become enriched.

HPLE-RP methods: to reduce the risk of heavy metal being enriched along with phlorotannins, resin purification (RP) methods were introduced [33,34]. With RP, heavy metal content in the phlorotannins extracted from macroalgae can be dramatically reduced [33] Kim et al. [33] compared four types of resins: HP-20, SP-580, XAD-7HP, and XAD-2. All four types of resins displayed effective purification of phlorotannins [33]. Among them, HP-20 resins displayed the highest absorption and desorption capacities, and this led to the best purification performance. 
Liquid chromatography (LC) is another widely utilized [13,25,45,55,73-76] separation method to isolate phlorotannins from algae extracts. It was used for phlorotannins from E. cava [55], E. stolonifera [45], fucales [13], F. vesiculosus [25,75,76], and fucus of the northern portuguese coastline [76]. It was also used for isolating and purifying pyrogallolphlroglucinol and phlorofucofuroeckol from brown algae [45,74]. Although HPLC works really well in laboratories, it is not suitable for large scale industrial production.

Liquid-liquid extraction (LLE) of phlorotannin: LLE is a separating method in which one polar and one non-polar solutions are used together [35-37,77]. Phlorotannins transfer from one liquid (polar) to another (non-polar). Chemical potential is the driving force of this transfer $[35-37,77]$. LLE is a commonly utilized separating method [35-37,77]. However, it had its own limitations in separating polarity-related compounds [35-37,77].

One-step centrifugal partition chromatography (CPC) method: Most liquid extraction methods mentioned above have common "cons", which are that "non-green" solvents are used during the extraction process [34]. A novel method was introduced in a recent study, in which a quick, one-step CPC (centrifugal partition chromatography) system was utilized to isolate four types of phlorotannins (dieckol, phlorofucofuroeckol-A, 7-phloroglucinol-6,6-bieckol, and pyrogallol-phloroglucinol-6,6-bieckol) from E. cava [78]. HPLC analyses indicated that all four types of phlorotannins, dieckol, phlorotucofuroeckol-A, 7-phloroglucinol-6,6-bieckol, and pyrogallol-phloroglucinol-6,6-bieckol, were extracted at $90 \%$ yield [79]. Compared to traditional approaches with long and complicated processes resulting in high losses of phlorotannins $[8,80]$, the loss of phlorotannins in one-step CPC was much reduced [78].

NEDES extraction: Another new development in phlorotannin extraction was the use of deep eutectic solvents (DESs). DES is a new class of ionic liquid (IL), typically formed by mixing choline chloride with hydrogen bond donors [81]. Environmentally friendly natural DESs (NADESs) were first explored for extracting active compounds from plant raw material $[82,83]$. Oblichinskaya et al. reported the first effort of using NADES to extract phrolotannins from brown algae F. vesiculosus L. and A. nodosum (L.) Le Jolis [84]. Ten NADES with different compositions were studied for their efficiency of extracting phlorotannins. They found that aqueous solutions of NADES based on choline chloride and lactic acid were the most efficient, comparable to those of traditional extractants such as $\mathrm{Me}_{2} \mathrm{CO}_{3}$ and EtOH and almost 10 times more efficient than pure NADES. As NADESs are clean green solvents, they could become an alternative to organic solvents to reduce the environmental footprint of phlorotannin extraction.

Following extraction, purification and characterization are the next steps. Molecular size-based separation is often used to purify different types of phlorotannins: these methods usually involve dialysis or ultrafiltration (UF) or a combination of the two [85]. Dialysis is an approach to isolate phlorotannins by different molecular weight $[79,86,87]$. The proper selection of membrane pore size is key to separating high molecular weight (MW) phlorotannins from low MW ones [79,86,87]. As for the UF system, with a fixed flow rate, UF can have a better performance [85]. The capacity of the UF system reported in the literature is still limited to lab-scale operations, ranging from $100 \mathrm{~mL}$ to $10 \mathrm{~L}$ [85]. One advantage of the UF system is its wide range of MW cutoff (MWCO), but industrial-ready UF for phlorotannins remains to be developed for large-scale applications [85].

After purification, NMR spectroscopy, mass spectrometry, and advanced chromatography are three common tools to evaluate the phlorotannin product to characterize the level of polymerization and the molecule weight distribution [88]. Phlorotannins could be indirectly quantified via the Folin-Ciocalteu (F-C) method, which measured the antioxidant activities in a sample. Although the F-C method is not selective for phlorotannins, it could yield quick readings with a simple operation, short turnaround time, and high throughput $[20,79,89-91]$; hence, it has been used for rapid determination of phlorotannin content in brown algae extracts [92]. In addition, computational chemistry was another useful tool [93-95]. Computational chemistry method can provide a cost-efficient supplementary tool to NMR spectroscopy [93-96]. Density functional theory (DFT) quantum chemical 
calculation was introduced to determine electronic structure of phlorotannins [96]. Natural bond orbital (NBO) was introduced to determine the donor acceptor stabilization energy caused by intramolecular and intermolecular hydrogen bonds in phlorotannins [96].

\section{Bioactivities of Phlorotannins}

As a group of tannins, phlorotannins from brown algae were shown to be effective in regulating several biochemical processes linked to the disruption of homeostasis in major chronic diseases $[18,39]$. They have been revealed to have a range of diverse biological functions and activities, such as antibacterial [7], anti-inflammatory [8], antioxidant [9], antidiabetic [10], anti-HIV [11], and anticancer [12,97,98] activities. They can form complexes with pro-oxidant proteins, chelate metal ions, or directly trap reactive oxygen species (ROS) to modulate cellular responses to stresses and/or injuries [99]. The most studied bioactivity of phlorotannins is their ability to scavenge radicals due to donation of their hydrogen atoms or electrons [100-105], which can be evaluated via 2, 2-diphenyl-1picrylhydrazyl (DPPH) radical-scavenging assay $[88,106,107]$, ferric reducing/antioxidant power (FRAP) assay [108], dichloro-dihydro-fluorescein diacetate (DCFH-DA) assay [109], trolox equivalent antioxidant capacity (TEAC) assay [110], and electron spin resonance spectroscopy [107].

Table 2 listed some of reported anti-inflammation effects of phlorotannins from literature. This list is by no means comprehensive, but it showcases the great potential of phlorotannins as anti-inflammation agents.

Table 2. Examples of reported anti-inflammatory effects of phlorotannins.

\begin{tabular}{|c|c|c|c|c|c|}
\hline Compounds & Origin & Anti-Inflammation Effects & Test System & Dosage * & Reference \\
\hline $\begin{array}{l}\text { Phlorotannins } \\
\text { extraction }\end{array}$ & $\begin{array}{l}\text { U. pinnatifida } \\
\text { sporophyll }\end{array}$ & Suppress $\mathrm{H}_{2} \mathrm{O}_{2}$-induced damage to cells. & RAW 264.7 cells & $2.5-80 \mu \mathrm{g} / \mathrm{mL}$ & {$[8]$} \\
\hline \multirow[t]{2}{*}{ Phloroglucinol } & \multirow[t]{2}{*}{ E. cava } & $\begin{array}{l}\text { Suppress tumor necrosis factor- } \alpha \text {, interleukin- } 1 \beta \text {, } \\
\text { interleukin-6, and prostaglandin E2 produced by } \\
\text { lipopolysaccharide. }\end{array}$ & HT1080 cells & $1,5,10 \mu \mathrm{M}$ & \multirow[t]{2}{*}[44]{} \\
\hline & & $\begin{array}{l}\text { Suppress matrix metalloproteinase express to } \\
\text { reduce chronic inflammation. }\end{array}$ & RAW264.7 cells & $1,5,10 \mu \mathrm{M}$ & \\
\hline $\begin{array}{l}\text { Phloroglucinol } \\
\text { and dieckol }\end{array}$ & E. cava & Suppress binding of IgE and FceRI. & KU812 cells & $\begin{array}{l}12.5,25,50 \\
100 \mu \mathrm{M}\end{array}$ & {$[111]$} \\
\hline $\begin{array}{l}\text { Phlorolfucofur- } \\
\text { oeckol }\end{array}$ & E. stolonifera & $\begin{array}{c}\text { Suppress iNOS and COX-2 gene's expression. } \\
\text { Suppress cytokines in macrophages, which } \\
\text { stimulate inflammatory activity. } \\
\text { Suppress transcriptional } \\
\text { activity of AP-1 and NF-kBs. } \\
\text { Suppress AKt and P38 MAPK's activation. }\end{array}$ & RAW 264.7 cells & $20 \mu \mathrm{M}$ & {$[45]$} \\
\hline
\end{tabular}

* Blank was used as negative control in all the cited research.

In addition, phlorotannins isolated from brown algae have also been widely reported to have anticancer bioactivities. For example, eckol from brown algae was shown to suppress tumor growth in vivo in S180 xenograft-bearing mice [46].

An intriguing aspect of phlorotannins is their anti-HIV activities. As listed in Table 3, phloroglucinol compounds from territorial plants (e.g., M. japonicus) and synthesized dimeric phloroglucinol were shown to be promising as part of a treatment plan against AIDS. 6,6'-bieckol isolated from E. cava was also shown to be effective. Other phlorotannin species should be further explored in future research. 
Table 3. Anti-HIV bioactivities of phloroglucinol and phlorotannins.

\begin{tabular}{|c|c|c|c|c|c|}
\hline Compounds & Origin & Anti-HIV Effects & Test System & Dosage * & Reference \\
\hline $6,6^{\prime}$-bieckol & E. cava & $\begin{array}{l}\text { Suppress HIV-1 (human immunodeficiency } \\
\text { virus type 1) induced syncytia formation, } \\
\text { production of vrial p24 antigen, effects of lytic. }\end{array}$ & $\begin{array}{l}\text { C8166 and } \\
\text { CEM-SS cells }\end{array}$ & $\begin{array}{c}0.5,2.5,5,25 \\
50,250,500 \mu \mathrm{M}\end{array}$ & [11] \\
\hline $\begin{array}{c}\text { Arzanol } \\
\text { (phloroglucinol } \\
\alpha \text {-pyrone) }\end{array}$ & $\begin{array}{l}\text { H. italicum ssp. } \\
\text { microphyllum }\end{array}$ & Suppress NF-кB and replication of HIV-1. & $\begin{array}{c}\text { human } \mathrm{T} \\
\text { lymphocyte cell } \\
\text { (Jurkat cell) }\end{array}$ & $5,10,25 \mu \mathrm{M}$ & [112] \\
\hline $\begin{array}{l}\text { Mallotophenone, } \\
\text { mallotojaponin } \\
\text { and mallo- } \\
\text { tochromene }\end{array}$ & M. japonicus & $\begin{array}{l}\text { Mallotophenone can suppress } \\
\text { HIV-reverse transcriptase. } \\
\text { Mallotophenone can suppress NF- } \kappa B \text {. }\end{array}$ & $\begin{array}{l}(\mathrm{rA}) \mathrm{n} .(\mathrm{dT}) 12-18 \\
\text { as primers }\end{array}$ & $10 \mu \mathrm{g} / \mathrm{mL}$ & [113] \\
\hline $\begin{array}{l}\text { Synthesized } \\
\text { dimeric } \\
\text { phloroglucinols }\end{array}$ & $\mathrm{N} / \mathrm{A}$ & Suppress HIV-1 NL4.3 virus in vitro. & $\begin{array}{l}\text { Human CD4+ T } \\
\text { cell line } \\
\text { (CEM-GFP) }\end{array}$ & $20 \mu \mathrm{g} /$ reaction & [114] \\
\hline $\begin{array}{c}\text { Prenylated } \\
\text { phloroglucinols }\end{array}$ & H. scruglii & Suppress replication of HIV-1. & RDDP assay & $3.5-8 \mu \mathrm{M}$ & [115] \\
\hline
\end{tabular}

* Blank was used as negative control in all the cited research.

Phlorotannins have also been demonstrated to be effective against diabetes [51-58]. These antidiabetic bioactivities included suppressing $\alpha$-glucosidase, phosphotyrosine phosphatase 1B (PTP 1B), aldose reductase, angiotensin-converting enzyme (ACE), and advanced glycation end products (AGEs) [51-58]. Table 4 listed some of the reported work on phlorotannins as potential antidiabetes treatments

Table 4. Antidiabetes functionality of phlorotannins.

\begin{tabular}{|c|c|c|c|c|c|}
\hline Compounds & Origin & Antidiabetic Activities & Test System & Dosage * & Reference \\
\hline Dieckol & E. cava & Suppress $\alpha$-glucosidase. & $\begin{array}{l}\text { Recombinant Human Aldo-keto } \\
\text { Reductase rhAKR1B10 }\end{array}$ & $10 \mu \mathrm{M}$ & {$[57]$} \\
\hline 6,6'-Bieckol & E. cava & Suppress PTP 1B. & Same as above & $10 \mu \mathrm{M}$ & {$[57]$} \\
\hline 7-Phloroeckol & E. cava & $\begin{array}{l}\text { Suppress ACE and } \\
\alpha \text {-glucosidase. }\end{array}$ & Same as above & $10 \mu \mathrm{M}$ & {$[57]$} \\
\hline \multirow[b]{2}{*}{ 2-phloroeckol } & \multirow[b]{2}{*}{ E. cava } & \multirow[b]{2}{*}{$\begin{array}{l}\text { Suppresss } \alpha \text {-glucosidase } \\
\text { and PTP 1B. }\end{array}$} & $\begin{array}{l}\text { Same as above and } \\
\text { pNPP substrate }\end{array}$ & $\begin{array}{c}10 \mu \mathrm{M} . \\
10 \text { and } 5 \mathrm{mM}\end{array}$ & \multirow[b]{2}{*}[54,55,57]{} \\
\hline & & & $\begin{array}{l}\alpha \text {-amylase, } \alpha \text {-glucosidase, } \\
\text { glucose induced protein } \\
\text { glycation and glucose diffusion } \\
\text { through dialysis membrane }\end{array}$ & $\begin{array}{l}133.33 \mu \mathrm{g} / \mathrm{mL} \\
\text { to } 6.66 \mu \mathrm{g} / \mathrm{mL}\end{array}$ & \\
\hline \multirow{3}{*}{$\begin{array}{l}\text { Phlorofucofur- } \\
\text { oeckol-A }\end{array}$} & \multirow{3}{*}{ E. cava } & \multirow{3}{*}{$\begin{array}{l}\text { Suppress } \alpha \text {-glucosidase, } \\
\text { PTP 1B, ACE, AGEs, and } \\
\text { Aldose reductase. }\end{array}$} & pNPP substrate & 25 and $10 \mathrm{mM}$ & \multirow{3}{*}[54-56,58]{} \\
\hline & & & AGE assay & $\begin{array}{l}200,100,50 \mathrm{mg} / \mathrm{mL} \\
\text { Positive contol: } \\
\text { aminoguanidine }\end{array}$ & \\
\hline & & & $\begin{array}{l}\alpha \text {-amylase, } \alpha \text {-glucosidase, } \\
\text { glucose-induced protein } \\
\text { glycation and glucose diffusion } \\
\text { through dialysis membrane }\end{array}$ & $\begin{array}{l}133.33 \mu \mathrm{g} / \mathrm{mL} \\
\text { to } 6.66 \mu \mathrm{g} / \mathrm{mL}\end{array}$ & \\
\hline $\begin{array}{l}\text { Phloroglucinol, } \\
\text { Eckol, Dieckol, } \\
\text { and Phlorofuco- } \\
\text { furoeckol }\end{array}$ & E. stolonifera & $\begin{array}{l}\text { All can suppress } \\
\alpha \text {-glucosidase }\end{array}$ & $\begin{array}{l}\text { Recombinant Human Aldo-keto } \\
\text { Reductase rhAKR1B10 and } \\
\text { type } 2 \text { diabetic db/db mice }\end{array}$ & $10 \mu \mathrm{M}$ & {$[53,57]$} \\
\hline
\end{tabular}

* Blank was used as negative control in all the cited research.

Last but not least, phlorotannins, as with other polyphenols, are good natural antioxidants that could bring health benefits to consumers [102-105,111,116]. ROS, hydrogen peroxide $\left(\mathrm{H}_{2} \mathrm{O}_{2}\right)$, hydroxyl radicals $(\mathrm{HO} \cdot)$, and superoxide anions can all be produced during oxygen metabolism [60,102-105,117-119], which could cause oxidative stress to cells that can lead to cell damages and cancerogenic mutations. Phlorotannins can scavenge these free radical species to remove them from harm's way. In addition, phlorotannins can 
act as total antioxidant with high reducing power. Free radical scavenging of phlorotannins extracted from S. aquifolium could be as high as $6.770 \pm 0.001 \mathrm{mg}^{-1}$ phlorotannin $\mathrm{g}^{-1}$ dry weight (DW), $6.1290 \pm 0.0200 \mathrm{mg}$ ascorbic acid g ${ }^{-1} \mathrm{DW}, 19.7210 \pm 0.0300 \mathrm{mg} \mathrm{FeSO}_{4} \mathrm{~g}^{-1}$ DW, and $76.28 \pm 0.20 \%$ of $25 \mathrm{mg} \mathrm{DPPH} \mathrm{mL}^{-1}$ extract [120]. Since higher amounts of phlorotannin content correlated to higher antioxidant activity $[9,121]$, better delivery of phlorotannins to improve their bioavailability would lead to elevated bioactivities as well.

When compared to other organs, skin was more vulnerable to UV (UV-A and UV-B radiation) radiation [122-124]. Exposure to long-term UV radiation can lead to skin cancers, photoaging, and even suppression of immune system [123,125-127]. Phlorotannins were shown to be effective in reducing photo-induced oxidative stress and ameliorating radiation damage to skins. In Table 5 below, different types of phlorotannins' antioxidant bioactivities are summarized.

Table 5. Antioxidant effects (including photo-oxidative stresses) of phlorotannins.

\begin{tabular}{|c|c|c|c|c|c|}
\hline Compounds & Origin & Antioxidant Effects & Test System & Dosage * & Reference \\
\hline \multirow[b]{2}{*}{ Dieckol } & \multirow[b]{2}{*}{ E. cava } & $\begin{array}{l}\text { Suppress UAB radiation } \\
\text { induced photo-oxidative stress. }\end{array}$ & Human fibroblaste cell & $5,50,250 \mu \mathrm{M}$ & \multirow[b]{2}{*}{ [59] } \\
\hline & & $\begin{array}{l}\text { Suppress UV-B radiation } \\
\text { induced cell damages (both } \\
\text { DNA damage and nuclear } \\
\text { fragmentation). }\end{array}$ & Human fibroblaste cell & $5,50,250 \mu \mathrm{M}$ & \\
\hline $\begin{array}{l}\text { Diphlorethohydro- } \\
\text { xycarmalol (DPHC) }\end{array}$ & Brown algae. & $\begin{array}{l}\text { DPHC can scavenge UV-B } \\
\text { radiation induced ROS; with } \\
\text { more DPHC added into the } \\
\text { treatment, cell viability } \\
\text { was uplifted. }\end{array}$ & Human fibroblast cells & $5,50,250 \mu \mathrm{M}$ & {$[62]$} \\
\hline Dieckol & E. cava & $\begin{array}{l}\text { Suppress cell damage induced } \\
\text { by UV-B radiation in vitro. } \\
\text { Suppress the level of ROS, nitric } \\
\text { oxide (NO) and cell death all } \\
\text { stimulated by UV-B radiation. }\end{array}$ & HaCaT cells & $\begin{array}{l}5,50,100, \text { and } \\
250 \mu \mathrm{M} .\end{array}$ & {$[63]$} \\
\hline $\begin{array}{l}\text { Phlorotannin extract } \\
\text { (PE) }\end{array}$ & E. cava & $\begin{array}{l}\text { Suppress levels of ROS and NO } \\
\text { induced by UV-B radiation. In } \\
\text { addition, cell death rate can be } \\
\text { reduced by pre-treating zebra } \\
\text { fish embryos with PE. }\end{array}$ & Zebra fish & $\begin{array}{l}5,50,100, \text { and } \\
250 \mu \mathrm{M} .\end{array}$ & {$[63]$} \\
\hline \multirow{2}{*}{$\begin{array}{l}\text { Diphlorethohydro- } \\
\text { xycarmalol (DPHC) }\end{array}$} & \multirow{2}{*}{ I. okamurae } & $\begin{array}{l}\text { Suppress high glucose-induced } \\
\text { oxidative stress. } \\
\text { Suppress level of ROS (reactive } \\
\text { oxygen species), NO (nitric } \\
\text { oxide) induced by high glucose. }\end{array}$ & $\begin{array}{l}\text { Human umbilical vein } \\
\text { endothelial cells }\end{array}$ & 5,25, and $50 \mu \mathrm{M}$ & \multirow{2}{*}[105,118]{} \\
\hline & & $\begin{array}{l}\text { Suppress high glucose induced } \\
\text { inducible nitric oxide synthase } \\
\text { (iNOS), cyclooxygenase-2 } \\
\text { (COX-2), and activation of } \\
\text { nuclear factor- } \\
\text { kappa B (NF-kB) activation. }\end{array}$ & $\begin{array}{l}\text { Human umbilical vein } \\
\text { endothelial cells }\end{array}$ & 5,25, and $50 \mu \mathrm{M}$ & \\
\hline
\end{tabular}

* Blank was used as negative control in all the cited research.

In addition to these bioactivities, phlorotannins were also reported to have antibacterial activities [128], antiadipogenic activity to ameliorate obesity [129,130], antivirus [116,131,132], anti-Alzheimer's disease [133], anti-arthritis [134] and antiallergic activities [111,135-137]. In summary, phlorotannins, as a group of highly active polyphenols, have great potential for applications in pharmaceutical, cosmetic, health care, and food industries.

\section{Nano-Sized Delivery Systems for Phlorotannins to Enhance Bioavailability and Bioactivities}

Although phlorotannins have all the highly desirable bioactivities and functionalities summarized in Section 3, their utilization as pharmaceuticals, therapeuticals, and food 
supplements is often limited due to their low bioavailability. Phlorotannins are unstable in the acidic condition of the gut and the alkaline condition of the small intestine; if not protected, they could easily be transformed and/or metabolized [138]. Phlorotannins are water soluble, but their absorption in the human gastrointestinal (GI) tract following consumption could be low, as evidence suggested that phlorotannins were mainly absorbed after metabolized in the large intestine [139], not in the stomach and the small intestine. A number of strategies have been used to increase the chemical stability of phlorotannins and to improve their transportation/absorption in the GI tract via nano-sized delivery systems that involved the encapsulation of phlorotannins in nanovectors, which offer protection against chemical/enzymatic transformation. These nano-systems could improve the distribution and overall bioavailability and bioactivity of the phlorotannins [65]. Such systems differ for the internal structures (e.g., core-shell-like vs. embedding matrixes) and the physical/chemical states of the encapsulated active ingredients (i.e., the phlorotannins), and their encapsulation efficiencies (EE, defined as the experimental loading/theoretical loading $\times 100 \%$ ) were different. Effective drug delivery systems usually require an $\mathrm{EE}$ to be higher than $60 \%$, which could be used as a reference to evaluate various phlorotannin nano-delivery systems.

Nano-sized delivery systems utilize nanoparticles or nanostructures with diameters ranging from 1-1000 nm to encapsulate/carry phlorotannins as the "payload". These nanoparticles, due to their size, exhibit properties and phenomena attributable to their dimension [140]. Nano-sized encapsulation systems can be made via several different approaches based on chemical, physical, and physiochemical principles. Chemical encapsulation (e.g., interfacial and in situ polymerization methods) usually requires the polymerization of monomers that cross-link with the payload [141]; physical encapsulation, on the other hand, usually uses already formed polymers (and natural polymers) to form a matrix in which the payload can be entrapped via various methods including air suspension, pan coating, spray drying, spray congealing, and micro-orifice systems [65]. Physiochemical methods (e.g., coacervation, phase separation, complex emulsion, meltable dispersion, and nanoprecipitation) aim to form stable nano-sized payload-carrying systems through particle size reduction processes [142]. Nanoencapsulation techniques, especially physical and physiochemical methods, have been [140] widely investigated for improving bioavailability and bioactivities of polyphenols by protecting the polyphenols against digestive transformation/degradation, reducing their toxicity and improving their water solubility [65]. Various nanocarrier systems, including cyclodextrins, nanospheres, nanocapsules, solid lipid nanoparticles, liposomes, and micelles, have been explored for polyphenols in general. Here, we will review a few specific cases in which phlorotannins were the payloads.

Shibata et al. [71] studied phlorotannins extracted from brown algae E. bicyclis, E. cava, and E. kurome; they showed that, with a liposome carrying system, the nanoencapsulated phlorotannins showed potent inhibition of phospholipid peroxidation at $1 \mu \mathrm{M}$, had significant radical scavenging activities against the superoxide anion (50\% effective concentration values: $6.5-8.4 \mu \mathrm{M})$ and DPPH (50\% effective concentration values: $12-26 \mu \mathrm{M})$, and were more effective compared to ascorbic acid and $\alpha$-tocopherol. Furthermore, a nanocarrier system of phlorotannins and soybean protein prepared by co-extrusion was shown to have a pronounced DPPH radical scavenging activity. The authors concluded that the nanoencapsulated phlorotannins could be a good functional food or supplement with anti-inflammatory activity.

Physical encapsulation was also applied to phrolotannins. In a recent effort, Cuong [69] reported nano phlorotannin powder made by spray-drying of phlorotannins isolated from $S$. serratum grown in Vietnam. The optimum spray drying condition was established as follows: a carrier-to-solution ratio of $10 \%$, compressed air pressure of $0.8 \mathrm{bar}$, liquid feed speed of $10 \mathrm{~mL} \mathrm{~min}^{-1}$, and inlet temperature of $110^{\circ} \mathrm{C}$. Under these conditions, the antioxidant activity of phlorotannin powder possessed total antioxidant activity at $4.347 \pm 0.018 \mathrm{~g}$ ascorbic acid equivalent $100 \mathrm{~g}^{-1} \mathrm{DP}$, reducing power activity at $9.390 \pm 0.024 \mathrm{~g} \mathrm{FeSO}_{4}$ 
equivalent $100 \mathrm{~g}^{-1} \mathrm{DP}$ and DPPH free radical scavenging activity at $70.02 \pm 0.26 \%$. The phlorotannin content and antioxidant activities of the nano-sized powder particles were affected by the spray drying condition $(p<0.05)$. These particles were nano-sized with morphology of irregular shapes. These nano phlorotannin powders displayed antioxidant activities for potential application in pharmaceuticals and nutritional supplements. In another effort [81], electrospun polycaprolactone (PCL)/phlorotannin micro/nanofibres containing different phlorotannin (from E. cava) concentrations (1,3, and $5 \mathrm{wt} \%$ ) were fabricated. Due to their hydrophilicity and water absorption ability, phlorotannin-containing fibrous mats exhibited outstanding wettability compared with pure PCL fibrous mats. The biocompatibility of the mats was examined in vitro using osteoblast-like cells (MG63). The phlorotannins were shown to promote alkaline phosphatase (ALP) activity and calcium deposition, which could induce bone regeneration. Cell viability (at $5 \mathrm{wt} \%$ phlorotannin), total protein content, ALP activity, and calcium deposition were all higher with $\mathrm{PCL} /$ phlorotannin mats than with pure PCL mats. These results suggest that electrospun nano PCL/phlorotannin fiber is a promising bioactive material for enhancing bone tissue growth. Lin et al. also demonstrated phlorotannin-encapsulating nanofibers with blended sodium alginate (SA) and poly(ethyleneoxide) (PEO) as the matrix via electrospinning, The optimum blending ratio to produce quality nanofibers was found to be 50:50:10 (SA/PEO/Ph); the nanofibers were shown to have an average diameter of $331 \mathrm{~nm}$. The fibers were then used as an antibacterial reagent against $S$. enteritidis on chicken at 4 and $25^{\circ} \mathrm{C}$ with great performance; the cell count drastically decreased from 6.20 to 3.28 $\log \mathrm{CFU} / \mathrm{g}$ at $4{ }^{\circ} \mathrm{C}$ and decreased from 8.80 to $2.53 \mathrm{Log} \mathrm{CFU} / \mathrm{g}$ at $25^{\circ} \mathrm{C}$. Their application significantly increased the shelf-life of chicken, which suggested that these nanofibers could be good food packaging materials due to the activities of the phlorotannins. Cui et al. [67] used a natural polymer (Momordica charantia polysaccharide (MCP)) as a nanofiber matrix to encapsulate phlorotannins via cold plasma treatment. The successfulness of PT loading into MCP nanofibers was confirmed using SEM, AFM, TGA, and DSC, as shown in Figure 3. After cold plasma treatment, the release efficiency of PT from the nanofibers was enhanced by $23.5 \%\left(4{ }^{\circ} \mathrm{C}\right)$ and $25 \%\left(25^{\circ} \mathrm{C}\right)$. In addition, both antioxidant and antibacterial activities of the MCP-phlorotannin nanofibers were markedly improved. These nanofibers could be a novel functional food packaging material. In this paper [67], the authors reported that both MCP and phlorotannin exhibit antidiabetic and antioxidant properties. They demonstrated that an MCP nanofiber-phlorotannin complex can enhance antioxidant effects. Thus, this MCP-phlorotannin complex was also used to make novel and enhanced food packaging materials.

Solid dispersion technique is another method that is widely used for generating nanocapsulation systems for wrapping a core material (the payload) with functionality (e.g., phlorotannin) inside a coating material. This technology can not only mask or retain flavor and increase solubility of the payload, but also protects it from degradation by environmental factors, and controls its release at the target site [82]. In a recent report, Qi et al. [66] investigated the potential of using polyvinylpyrrolidone (PVP) as the coating to produce nanocapsulated PVP-phlorotannin complexes (Figure 4) with improved bioactivities and bioavailability. Different loading ratios of PVP vs. phlorotannin were investigated, and an optimum ratio of 8:1 (w/w) was established. As shown in Figure 5, the results indicated that the PVP-phlorotannin nanoparticles showed a slow and sustained kinetic release of phlorotannin in simulated gastrointestinal fluids; they were non-toxic to $\mathrm{HaCaT}$ keratinocytes (i.e., skin cells), and they could reduce the generation of endogenous reactive oxygen species (ROS). A PVP-based solid dispersion system would be a good choice for making better nano-sized delivery systems for phlorotannins in medicine, food, and cosmetics $[66,83]$. 

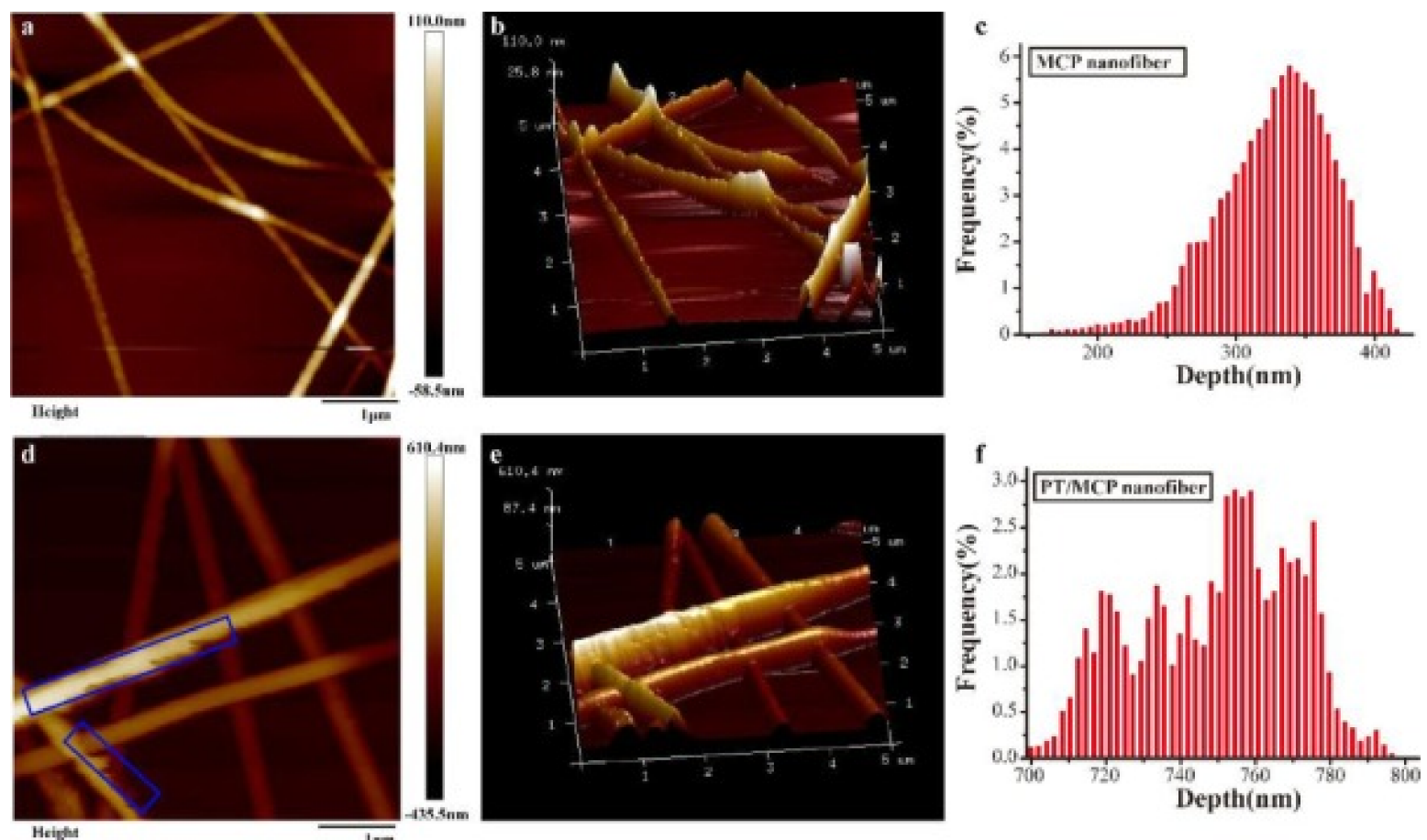

Figure 3. Surface, three-dimensional AFM images, and depth distribution of MCP nanofibers (a-c) and PT/MCP nanofibers (d-f). Replicated from Cui et al. [67] with permission.

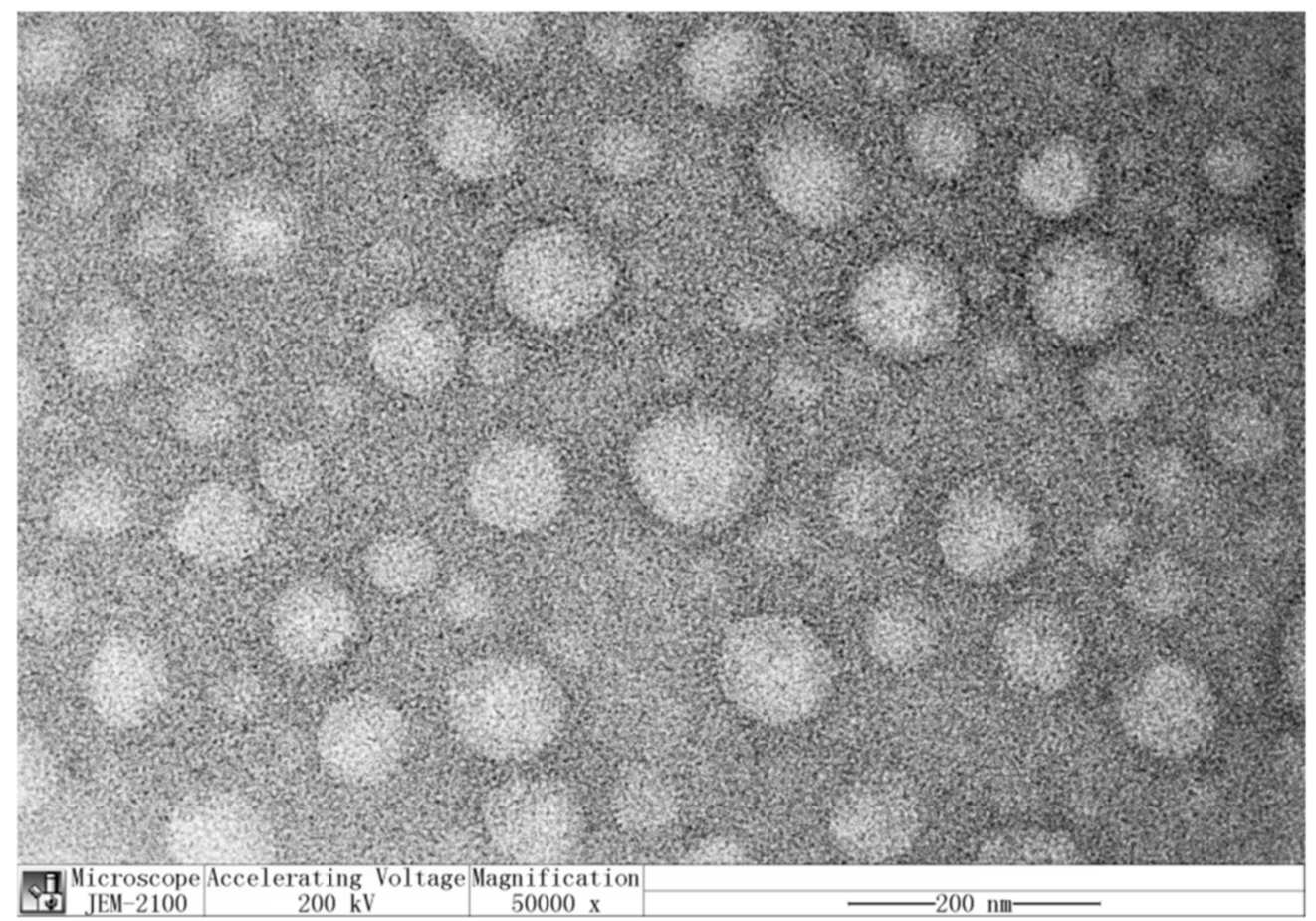

Figure 4. Transmission electron microscopy (TEM) image of phlorotannin@PVP nanoparticles (PPNPS). The concentration of PPNPS was $1 \mathrm{mg} / \mathrm{mL}$, replicated from Qi et al. [66] with permission. 


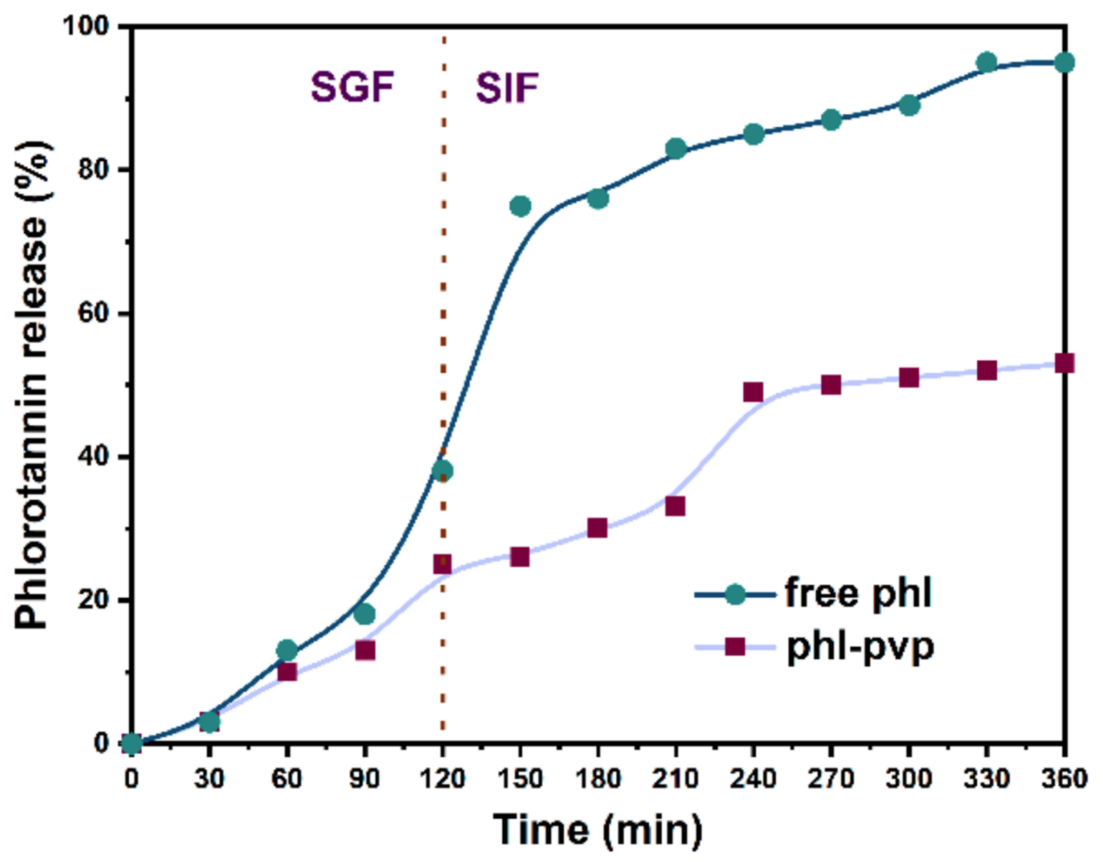

Figure 5. Release profile of free phlorotannin and Phlorotannin@PVP nanoparticles (PPNPS) (1:8, w/w) in simulated gastrointestinal fluids, replicated from Qi et al. [66] with permission.

An interesting development with phlorotannin nano carriers was the synthesis of metallic nanoparticles (typically Au and Ag), with phlorotannins serving as the reducing agent. In these processes, the metallic nanoparticles formed have phlorotannin coating, hence can serve as delivery vehicles for phlorotannins (PhTs). Kim et al. [68] demonstrated that $\mathrm{Au}$ nanoparticles were formed within 1 min while mixing phlorotannins extract from E. cava with chloroauric acid at $80^{\circ} \mathrm{C}$, and the $\mathrm{Au}-\mathrm{PhT}$ nanoparticles were $30 \pm 0.25 \mathrm{~nm}$ and displayed promising antimicrobial activities. Machado et al [70] compared phlorotannins extracts from two macroalgae, C. baccata (CB) and C. tamariscifolia (CT), for their abilities to form gold nanoparticles; the results showed that CT possess three times more reducing power, almost four times more phenolic content, and four times more DPPH scavenging activity than $\mathrm{CB}$, and the gold nanoparticles produced presented a non-cytotoxic profile in lower concentrations in mouse cell line L929 and human cell line BJ5-ta, which were efficient in cell regeneration, although with some differences between both species. The CT-gold nanoparticle complex had significantly better antioxidant bioactivity than the CB-gold nanoparticle complexes. Shim et al. [69] reported a green synthesis process for silver nanoparticles. The phlorotannin-silver nanoparticle complex has an average size of around $40 \mathrm{~nm}$ with spherical structure. These phlorotannin-silver nanoparticle complexes displayed antibacterial and antioxidant bioactivities. In particular, they exhibited a strong apoptotic anticancer activity against human cervical cancer cells that was not observed for phlorotannin, which suggested that the synergistic effects of phlorotannins and silver nanoparticles could further enhance their anticancer activities (Figure 6). Abedel-Raouf et al. [74] reported that phlorotannin isolated from G. elongate can be utilized to synthesize phlorotannin-gold nanoparticle complexes. Several shapes of phlorotannin-gold nanoparticles were formed, as shown by TEM. Triangular, truncated triangular, hexagonal, and rod shapes were detected. The sizes of these phlorotannin-gold nanoparticle complexes were around 3-77 $\mathrm{nm}$. Antibacterial bioactivity was tested against E. coli, K. pneumoniae, and MRSA. Phlorotannin-gold nanoparticle complexes of $13 \mathrm{~nm}$ demonstrated the best antibacterial performance. It could be concluded that phlorotannininduced $\mathrm{Au}$ and/or Ag nanoparticles could potentially become effective antibacterial, antiviral, and antioxidant reagents [75]. 
A

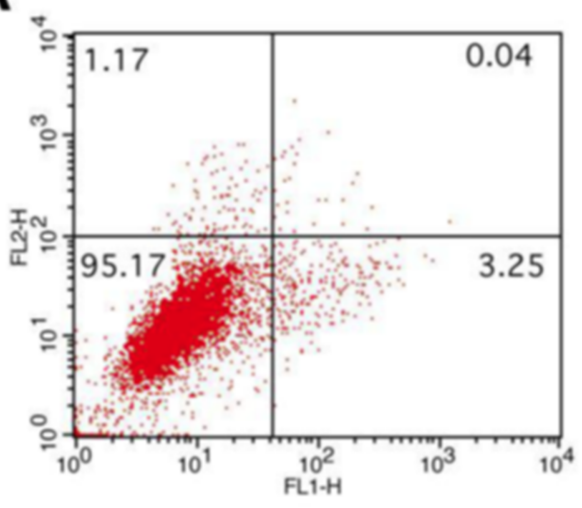

C

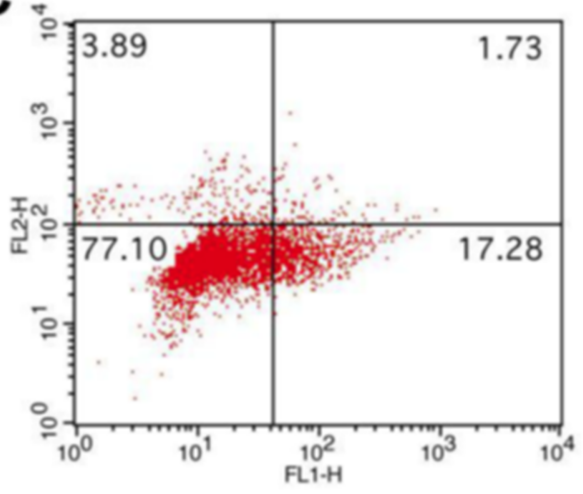

B

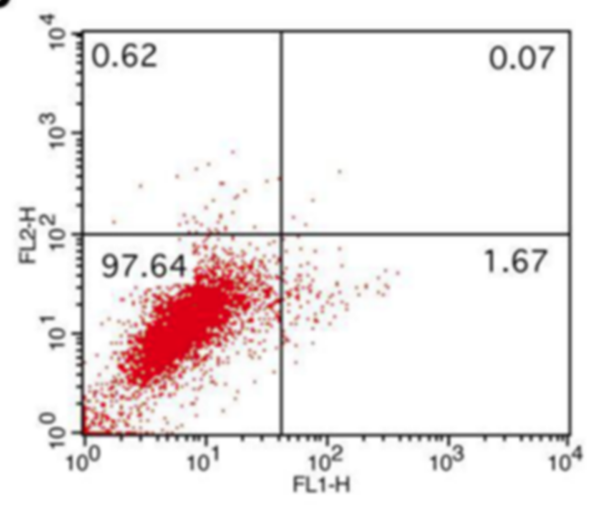

D

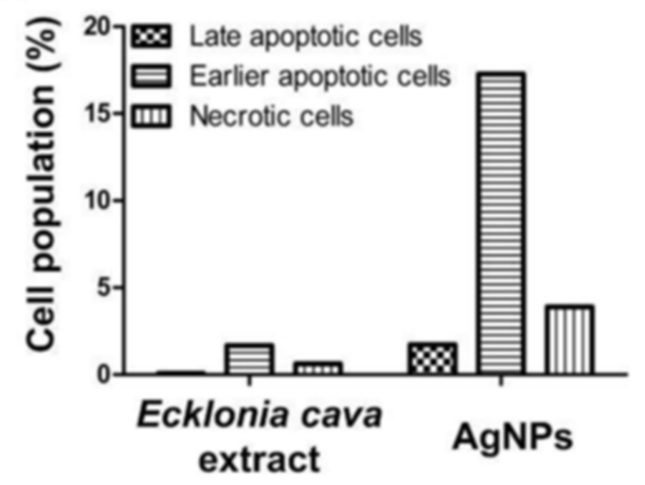

Figure 6. Annexin/PI staining of: (A) untreated HeLa cells; (B) HeLa cells treated with $250 \mu \mathrm{g} / \mathrm{mL}$ of E. cava extracts; (C) HeLa cells treated with $250 \mu \mathrm{g} / \mathrm{mL}$ of biosynthesized AgNPs; and (D) relative cell population of HeLa cells after treatment with E. cava extracts and biosynthesized AgNPs. Replicated from Shim et al. [69] with permission.

\section{Conclusions}

In this review, we summarized extraction techniques and bioactivities of phlorotannins and the strategies that have been explored via utilization of nano-sized delivery systems to improve their bioavailability and bioactivities. With nano-carriers protecting phlorotannins against GI tract biotransformation and degradation, phlorotannins can be released in a controlled manner to enhance their therapeutic functionalities, which included anticancer, anti-inflammatory, anti-HIV, antidiabetic, antioxidant, antibacterial activities, etc. This review serves as a roadmap for the development of more effective phlorotannin utilization strategies to fully take advantage of the tremendous potential of these algae-derived natural compounds as drugs and nutritional supplements for the pharmaceutical, food, and cosmetics industries.

Author Contributions: Conceptualization, X.L. and C.Y.; data curation, T.T.; writing-original draft preparation, T.T.; writing-review and editing, X.L. and C.Y.; visualization, T.T. and C.Y.; supervision, C.Y.; project administration, C.Y.; funding acquisition, X.L. All authors have read and agreed to the published version of the manuscript.

Funding: This work was partially funded by National Key R\&D Program of China (2018YFD0901000) and National Natural Science Foundation of China (31801554).

Data Availability Statement: Not applicable.

Conflicts of Interest: The authors declare no conflict of interest. 


\section{References}

1. Van Alstyne, K.; McCarthy, J.J.; Hustead, C.L.; Kearns, L.J. Phlorotannin Allocation Among Tissues of Northeastern Pacific Kelps and Rockweeds. J. Phycol. 1999, 35, 483-492. [CrossRef]

2. Heffernan, N.; Brunton, N.P.; Fitzgerald, R.J.; Smyth, T.J. Profiling of the Molecular Weight and Structural Isomer Abundance of Macroalgae-Derived Phlorotannins. Mar. Drugs 2015, 13, 509-528. [CrossRef] [PubMed]

3. Kim, R.; Suh, Y.; Yoo, K.; Cui, Y.; Hwang, E.; Kim, H.; Kang, J.; Kim, M.; Lee, Y.Y.; Lee, S. Phloroglucinol suppresses metastatic ability of breast cancer cells by inhibition of epithelial-mesenchymal cell transition. Cancer Sci. 2014, 106, 94-101. [CrossRef] [PubMed]

4. Yoon, J.-Y.; Choi, H.; Jun, H.-S. The Effect of Phloroglucinol, A Component of Ecklonia cava Extract, on Hepatic Glucose Production. Mar. Drugs 2017, 15, 106. [CrossRef]

5. Airanthi, M.W.-A.; Hosokawa, M.; Miyashita, K. Comparative Antioxidant Activity of Edible Japanese Brown Seaweeds. J. Food Sci. 2010, 76, C104-C111. [CrossRef] [PubMed]

6. Aoki, K.; Taketo, M.M. Adenomatous polyposis coli (APC): A multi-functional tumor suppressor gene. J. Cell Sci. 2007, 120, 3327-3335. [CrossRef] [PubMed]

7. Nagayama, K.; Iwamura, Y.; Shibata, T.; Hirayama, I.; Nakamura, T. Bactericidal activity of phlorotannins from the brown alga Ecklonia kurome. J. Antimicrob. Chemother. 2002, 50, 889-893. [CrossRef] [PubMed]

8. Dong, X.; Bai, Y.; Xu, Z.; Shi, Y.; Sun, Y.; Janaswamy, S.; Yu, C.; Qi, H. Phlorotannins from Undaria pinnatifida Sporophyll: Extraction, Antioxidant, and Anti-Inflammatory Activities. Mar. Drugs 2019, 17, 434. [CrossRef]

9. Wang, T.; Jónsdóttir, R.; Liu, H.; Gu, L.; Kristinsson, H.G.; Raghavan, S.; Ólafsdóttir, G. Antioxidant Capacities of Phlorotannins Extracted from the Brown Algae Fucus vesiculosus. J. Agric. Food Chem. 2012, 60, 5874-5883. [CrossRef]

10. Kim, H.; Kong, C.-S.; Lee, J.I.; Kim, H.; Baek, S.; Seo, Y. Evaluation of Inhibitory Effect of Phlorotannins from Ecklonia cava on Triglyceride Accumulation in Adipocyte. J. Agric. Food Chem. 2013, 61, 8541-8547. [CrossRef]

11. Artan, M.; Li, Y.; Karadeniz, F.; Lee, S.-H.; Kim, M.-M.; Kim, S.-K. Anti-HIV-1 activity of phloroglucinol derivative, 6,6'-bieckol, from Ecklonia cava. Bioorganic Med. Chem. 2008, 16, 7921-7926. [CrossRef]

12. Ahn, J.-H.; Yang, Y.-I.; Lee, K.-T.; Choi, J.-H. Dieckol, isolated from the edible brown algae Ecklonia cava, induces apoptosis of ovarian cancer cells and inhibits tumor xenograft growth. J. Cancer Res. Clin. Oncol. 2014, 141, 255-268. [CrossRef] [PubMed]

13. Ferreres, F.; Lopes, G.; Gil-Izquierdo, A.; Andrade, P.B.; Sousa, C.; Mouga, T.; Valentão, P. Phlorotannin Extracts from Fucales Characterized by HPLC-DAD-ESI-MSn: Approaches to Hyaluronidase Inhibitory Capacity and Antioxidant Properties. Mar. Drugs 2012, 10, 2766-2781. [CrossRef] [PubMed]

14. Li, Y.-X.; Wijesekara, I.; Kim, S.-K. Phlorotannins as bioactive agents from brown algae. Process. Biochem. 2011, 46, 2219-2224. [CrossRef]

15. Kamiya, M.; Nishio, T.; Yokoyama, A.; Yatsuya, K.; Nishigaki, T.; Yoshikawa, S.; Ohki, K. Seasonal variation of phlorotannin in sargassacean species from the coast of the Sea of Japan. Phycol. Res. 2010, 58, 53-61. [CrossRef]

16. Jégou, C.; Kervarec, N.; Cérantola, S.; Bihannic, I.; Stiger-Pouvreau, V. NMR use to quantify phlorotannins: The case of Cystoseira tamariscifolia, a phloroglucinol-producing brown macroalga in Brittany (France). Talanta 2015, 135, 1-6. [CrossRef]

17. Imbs, T.I.; Zvyagintseva, T.N. Phlorotannins are Polyphenolic Metabolites of Brown Algae. Russ. J. Mar. Biol. 2018, 44, 263-273. [CrossRef]

18. Shibata, T.; Yamaguchi, K.; Nagayama, K.; Kawaguchi, S.; Nakamura, T. Inhibitory activity of brown algal phlorotannins against glycosidases from the viscera of the turban shell Turbo cornutus. Eur. J. Phycol. 2002, 37, 493-500. [CrossRef]

19. Isaza Martínez, J.H.; Torres Castañeda, H.G. Preparation and Chromatographic Analysis of Phlorotannins. J. Chromatogr. Sci. 2013, 51, 825-838. [CrossRef]

20. Parys, S.; Rosenbaum, A.; Kehraus, S.; Reher, G.; Glombitza, K.-W.; König, G.M. Evaluation of Quantitative Methods for the Determination of Polyphenols in Algal Extracts. J. Nat. Prod. 2007, 70, 1865-1870. [CrossRef]

21. Vo, T.-S.; Ngo, D.-H.; Kim, S.-K. Marine algae as a potential pharmaceutical source for anti-allergic therapeutics. Process Biochem. 2012, 47, 386-394. [CrossRef]

22. Stern, J.L.; Hagerman, A.E.; Steinberg, P.D.; Mason, P.K. Phlorotannin-protein interactions. J. Chem. Ecol. 1996, 22, 1877-1899. [CrossRef]

23. Glombitza, K.-W.; Pauli, K.-W.G.K. Fucols and Phlorethols from the Brown Alga Scytothamnus australis Hook. et Harv. (Chnoosporaceae). Bot. Mar. 2003, 46, 28. [CrossRef]

24. Kim, J.; Um, M.; Yang, H.; Kim, I.; Lee, C.; Kim, Y.; Yoon, M.; Kim, Y.; Kim, J.; Cho, S. Method development and validation for dieckol in the standardization of phlorotannin preparations. Fish. Aquat. Sci. 2016, 19, 1. [CrossRef]

25. Koivikko, R.; Loponen, J.; Pihlaja, K.; Jormalainen, V. High-performance liquid chromatographic analysis of phlorotannins from the brown alga Fucus Vesiculosus. Phytochem. Anal. 2007, 18, 326-332. [CrossRef]

26. Venkatesan, J.; Kim, S.-K.; Shim, M.S. Antimicrobial, Antioxidant, and Anticancer Activities of Biosynthesized Silver Nanoparticles Using Marine Algae Ecklonia cava. Nanomaterials 2016, 6, 235. [CrossRef]

27. Pacheco, L.V.; Parada, J.; Pérez-Correa, J.R.; Mariotti-Celis, M.S.; Erpel, F.; Zambrano, A.; Palacios, M. Bioactive Polyphenols from Southern Chile Seaweed as Inhibitors of Enzymes for Starch Digestion. Mar. Drugs 2020, 18, 353. [CrossRef]

28. Parada, J.; Perez-Correa, J.; Pérez-Jiménez, J. Design of low glycemic response foods using polyphenols from seaweed. J. Funct. Foods 2019, 56, 33-39. [CrossRef]

29. Valenzuela, J.C.; Vergara-Salinas, J.R.; Perez-Correa, J.R. Advances in Technologies for Producing Food-Relevant Polyphenols; Valenzuela, J.C., Vergara-Salinas, J.R., Perez-Correa, J.R., Eds.; CRC Press: Boca Raton, FL, USA, 2016; ISBN 9781498714990. 
30. Fraser, C.I.; Velásquez, M.; Nelson, W.A.; Macaya, E.C.; Hay, C.H. The Biogeographic Importance of Buoyancy in Macroalgae: A Case Study of the Southern Bull-Kelp Genus Durvillaea (Phaeophyceae), Including Descriptions of Two New Species 1. J. Phycol. 2020, 56, 23-36. [CrossRef] [PubMed]

31. Heavisides, E.; Rouger, C.; Reichel, A.F.; Ulrich, C.; Wenzel-Storjohann, A.; Sebens, S.; Tasdemir, D. Seasonal Variations in the Metabolome and Bioactivity Profile of Fucus vesiculosus Extracted by an Optimised, Pressurised Liquid Extraction Protocol. Mar. Drugs 2018, 16, 503. [CrossRef] [PubMed]

32. Sanz-Pintos, N.; Pérez-Jiménez, J.; Buschmann, A.H.; Vergara-Salinas, J.R.; Pérez-Correa, J.R.; Saura-Calixto, F. Macromolecular Antioxidants and Dietary Fiber in Edible Seaweeds. J. Food Sci. 2017, 82, 289-295. [CrossRef]

33. Kim, J.; Yoon, M.; Yang, H.; Jo, J.; Han, D.; Jeon, Y.-J.; Cho, S. Enrichment and purification of marine polyphenol phlorotannins using macroporous adsorption resins. Food Chem. 2014, 162, 135-142. [CrossRef] [PubMed]

34. Leyton, A.; Vergara-Salinas, J.; Perez-Correa, J.; Lienqueo, M. Purification of phlorotannins from Macrocystis pyrifera using macroporous resins. Food Chem. 2017, 237, 312-319. [CrossRef] [PubMed]

35. Huddleston, J.G.; Willauer, H.D.; Swatloski, R.P.; Visser, A.E.; Rogers, R.D. Room temperature ionic liquids as novel media for 'clean' liquid-liquid extraction. Chem. Commun. 1998, 80, 1765-1766. [CrossRef]

36. Seddon, K.R. Ionic Liquids for Clean Technology. J. Chem. Technol. Biotechnol. 1997, 68, 43. [CrossRef]

37. Lo, T.C. Handbook of Separations Techniques for Chemical Engineers; Schwietzer, P.A., Ed.; McGraw-Hill: New York, NY, USA, 1996; pp. $450-529$.

38. Chowdhury, M.T.H.; Bangoura, I.; Kang, J.-Y.; Cho, J.Y.; Joo, J.; Choi, Y.S.; Hwang, D.S.; Hong, Y.-K. Comparison of Ecklonia Cava, E. Stolonifera, and Eisenia Bicyclis for Phlorotannin Extraction. J. Environ. Biol. 2014, 35, 713-719. [PubMed]

39. Shin, H.-C.; Hwang, H.J.; Kang, K.J.; Lee, B.H. An antioxidative and antiinflammatory agent for potential treatment of osteoarthritis fromEcklonia cava. Arch. Pharm. Res. 2006, 29, 165-171. [CrossRef] [PubMed]

40. Kumar, V.; Abbas, A.K.; Fausto, N.; Aster, J.C. Robbins and Cotran Pathologic Basis of Disease, Professional Edition: Expert Consult; Elsevier Health Sciences: London, UK, 2014.

41. Sanjeewa, K.K.A.; Kim, E.-A.; Son, K.-T.; Jeon, Y.-J. Bioactive properties and potentials cosmeceutical applications of phlorotannins isolated from brown seaweeds: A review. J. Photochem. Photobiol. B Biol. 2016, 162, 100-105. [CrossRef] [PubMed]

42. Murphy, T.F. The role of bacteria in airway inflammation in exacerbations of chronic obstructive pulmonary disease. Curr. Opin. Infect. Dis. 2006, 19, 225-230. [CrossRef]

43. Milian, E.; Diaz, A.M. Allergy to House Dust Mites and Asthma. Health Sci. J. 2004, 23, 47-57.

44. Kim, M.-M.; Kim, S.-K. Effect of phloroglucinol on oxidative stress and inflammation. Food Chem. Toxicol. 2010, 48, 2925-2933. [CrossRef] [PubMed]

45. Kim, A.-R.; Lee, M.-S.; Shin, T.-S.; Hua, H.; Jang, B.-C.; Choi, J.-S.; Byun, D.-S.; Utsuki, T.; Ingram, D.; Kim, H.-R. Phlorofucofuroeckol A inhibits the LPS-stimulated iNOS and COX-2 expressions in macrophages via inhibition of NF- $\mathrm{kB}$, Akt, and p38 MAPK. Toxicol. In Vitr. 2011, 25, 1789-1795. [CrossRef] [PubMed]

46. Zhang, M.-Y.; Guo, J.; Hu, X.-M.; Zhao, S.-Q.; Li, S.-L.; Wang, J. An in vivo anti-tumor effect of eckol from marine brown algae by improving the immune response. Food Funct. 2019, 10, 4361-4371. [CrossRef] [PubMed]

47. Abdelsalam, S.S.; Korashy, H.M.; Zeidan, A.; Agouni, A. The Role of Protein Tyrosine Phosphatase (PTP)-1B in Cardiovascular Disease and Its Interplay with Insulin Resistance. Biomolecules 2019, 9, 286. [CrossRef]

48. Peng, J.; Yuan, J.-P.; Wu, C.-F.; Wang, J.-H. Fucoxanthin, a Marine Carotenoid Present in Brown Seaweeds and Diatoms: Metabolism and Bioactivities Relevant to Human Health. Mar. Drugs 2011, 9, 1806-1828. [CrossRef] [PubMed]

49. Lee, S.-H.; Jeon, Y.-J. Anti-diabetic effects of brown algae derived phlorotannins, marine polyphenols through diverse mechanisms. Fitoterapia 2013, 86, 129-136. [CrossRef]

50. Moon, H.E.; Islam, N.; Ahn, B.R.; Chowdhury, S.S.; Sohn, H.S.; Jung, H.A.; Choi, J.S. Protein Tyrosine Phosphatase 1B and $\alpha$-Glucosidase Inhibitory Phlorotannins from Edible Brown Algae, Ecklonia stolonifera and Eisenia bicyclis. Biosci. Biotechnol. Biochem. 2011, 75, 1472-1480. [CrossRef]

51. Gunathilaka, M.D.T.L.; Ranasinghe, P.; Samarakoon, K.W.; Peiris, L.C.D. In-Vitro Anti-Diabetic Activity of Polyphenole-Rich Extract from Marine Brown Algae Choonospora minima (Hering 1841). Basic Appl. Sci. 2011, 22, 315-326.

52. Jung, H.A.; Yoon, N.Y.; Woo, M.-H.; Choi, J.S. Inhibitory activities of extracts from several kinds of seaweeds and phlorotannins from the brown alga Ecklonia stolonifera on glucose-mediated protein damage and rat lens aldose reductase. Fish. Sci. 2008, 74, 1363-1365. [CrossRef]

53. Lee, J.Y.; Kim, S.M.; Jung, W.-S.; Song, D.-G.; Um, B.-H.; Son, J.-K.; Pan, C.-H. Phlorofucofuroeckol-A, a potent inhibitor of aldo-keto reductase family 1 member B10, from the edible brown alga Eisenia bicyclis. J. Korean Soc. Appl. Biol. Chem. 2012, 55, 721-727. [CrossRef]

54. Unnikrishnan, P.S.; Suthindhiran, K.; Jayasri, M.A. Inhibitory Potential of Turbinaria ornate against Key Metabolic Enzymes Linked to Diabetes. BioMed Res. Int. 2014, 2014, 1-10. [CrossRef]

55. Heo, S.-J.; Ko, S.-C.; Cha, S.-H.; Kang, D.-H.; Park, H.-S.; Choi, Y.-U.; Kim, D.; Jung, W.-K.; Jeon, Y.-J. Effect of phlorotannins isolated from Ecklonia cava on melanogenesis and their protective effect against photo-oxidative stress induced by UV-B radiation. Toxicol. In Vitr. 2009, 23, 1123-1130. [CrossRef]

56. Martindale, J.L.; Holbrook, N.J. Cellular response to oxidative stress: Signaling for suicide and survival. J. Cell. Physiol. 2002, 192, 1-15. [CrossRef] 
57. Heo, S.-J.; Ko, S.-C.; Kang, S.-M.; Cha, S.-H.; Lee, S.-H.; Kang, D.-H.; Jung, W.-K.; Affan, A.; Oh, C.; Jeon, Y.-J. Inhibitory effect of diphlorethohydroxycarmalol on melanogenesis and its protective effect against UV-B radiation-induced cell damage. Food Chem. Toxicol. 2010, 48, 1355-1361. [CrossRef]

58. Ko, S.-C.; Cha, S.-H.; Heo, S.-J.; Lee, S.-H.; Kang, S.-M.; Jeon, Y.-J. Protective effect of Ecklonia cava on UVB-induced oxidative stress: In vitro and in vivo zebrafish model. Environ. Biol. Fishes 2011, 23, 697-708. [CrossRef]

59. Cha, S.-H.; Ko, C.-I.; Kim, D.; Jeon, Y.-J. Protective effects of phlorotannins against ultraviolet B radiation in zebrafish (Danio rerio). Vet. Dermatol. 2011, 23, 51-e12. [CrossRef] [PubMed]

60. Kim, K.C.; Piao, M.J.; Zheng, J.; Yao, C.W.; Cha, J.W.; Kumara, M.H.S.R.; Han, X.; Kang, H.K.; Lee, N.H.; Hyun, J.W. Fucodiphlorethol G Purified from Ecklonia cava Suppresses Ultraviolet B Radiation-Induced Oxidative Stress and Cellular Damage. Biomol. Ther. 2014, 22, 301-307. [CrossRef] [PubMed]

61. Bai, Y.; Sun, Y.; Gu, Y.; Zheng, J.; Yu, C.; Qi, H. Preparation, Characterization and Antioxidant Activities of Kelp Phlorotannin Nanoparticles. Molecules 2020, 25, 4550. [CrossRef] [PubMed]

62. Conte, R.; Calarco, A.; Napoletano, A.; Valentino, A.; Margarucci, S.; Di Cristo, F.; Di Salle, A.; Peluso, G. Newly added information, please confirm.Polyphenols Nanoencapsulation for Therapeutic Applications. J. Biomol. Res. Ther. 2016, 5, 139. [CrossRef]

63. Cui, H.; Yang, X.; Abdel-Samie, M.A.-S.; Lin, L. Cold plasma treated phlorotannin/Momordica charantia polysaccharide nanofiber for active food packaging. Carbohydr. Polym. 2020, 239, 116214. [CrossRef]

64. Venkatesan, J.; Manivasagan, P.; Kim, S.-K.; Kirthi, A.V.; Marimuthu, S.; Rahuman, A.A. Marine algae-mediated synthesis of gold nanoparticles using a novel Ecklonia cava. Bioprocess Biosyst. Eng. 2014, 37, 1591-1597. [CrossRef]

65. Cuong, D.X. Antioxidant Nano Phlorotannin Powder from Brown Algae Sargassum serratum: Spray Drying, Antioxidant Activities, Physic-Chemical Characterization. J. Pharm. Res. Int. 2020, 32, 71-85. [CrossRef]

66. Machado, S.; Gonçalves, A.; González-Ballesteros, N.; Magalhães, L.; Sárria, M.; Rodríguez-Argüelles, M.C.; Gomes, A.C. Comparing toxicity and bioactivity of gold nanoparticles synthetized using two brown algae Cystoseira sp. Front. Mar. Sci. 2019, 6, 155. [CrossRef]

67. Mmola, M.; Le Roes-Hill, M.; Durrell, K.; Bolton, J.J.; Sibuyi, N.; Meyer, M.E.; Beukes, D.R.; Antunes, E. Enhanced Antimicrobial and Anticancer Activity of Silver and Gold Nanoparticles Synthesised Using Sargassum incisifolium Aqueous Extracts. Molecules 2016, 21, 1633. [CrossRef]

68. Palanisamy, S.; Rajasekar, P.; Vijayaprasath, G.; Ravi, G.; Manikandan, R.; Prabhu, N.M. A green route to synthesis silver nanoparticles using Sargassum polycystum and its antioxidant and cytotoxic effects: An in vitro analysis. Mater. Lett. 2017, 189, 196-200. [CrossRef]

69. Abdel-Raouf, N.; Al-Enazi, N.M.; Ibraheem, I.B. Green biosynthesis of gold nanoparticles using Galaxaura elongata and characterization of their antibacterial activity. Arab. J. Chem. 2017, 10, S3029-S3039. [CrossRef]

70. González-Ballesteros, N.; Rodríguez-Argüelles, M.C.; Lastra-Valdor, M.; González-Mediero, G.; Rey-Cao, S.; Grimaldi, M.; Cavazza, A.; Bigi, F. Synthesis of silver and gold nanoparticles by Sargassum muticum biomolecules and evaluation of their antioxidant activity and antibacterial properties. J. Nanostruct. Chem. 2020, 10, 317-330. [CrossRef]

71. Wang, C.; Chen, X.; Nakamura, Y.; Yu, C.; Qi, H. Fucoxanthin activities motivate its nano/micro-encapsulation for food or nutraceutical application: A review. Food Funct. 2020, 11, 9338-9358. [CrossRef] [PubMed]

72. Roleda, M.Y.; Marfaing, H.; Desnica, N.; Jónsdóttir, R.; Skjermo, J.; Rebours, C.; Nitschke, U. Variations in polyphenol and heavy metal contents of wild-harvested and cultivated seaweed bulk biomass: Health risk assessment and implication for food applications. Food Control 2019, 95, 121-134. [CrossRef]

73. Kang, S.-M.; Lee, S.-H.; Heo, S.-J.; Kim, K.-N.; Jeon, Y.-J. Evaluation of antioxidant properties of a new compound, pyrogallolphloroglucinol-6,6'-bieckol isolated from brown algae, Ecklonia cava. Nutr. Res. Pract. 2011, 5, 495-502. [CrossRef]

74. Steevensz, A.J.; MacKinnon, S.L.; Hankinson, R.; Craft, C.; Connan, S.; Stengel, D.B.; Melanson, J.E. Profiling Phlorotannins in Brown Macroalgae by Liquid Chromatography-High Resolution Mass Spectrometry. Phytochem. Anal. 2012, $23,547-553$. [CrossRef] [PubMed]

75. Koivikko, R.; Eränen, J.K.; Loponen, J.; Jormalainen, V. Variation of Phlorotannins Among Three Populations of Fucus vesiculosus as Revealed by HPLC and Colorimetric Quantification. J. Chem. Ecol. 2007, 34, 57-64. [CrossRef] [PubMed]

76. Lopes, G.; Barbosa, M.; Vallejo, F.; Gil-Izquierdo, Á.; Andrade, P.B.; Valentão, P.; Pereira, D.; Ferreres, F. Profiling phlorotannins from Fucus spp. of the Northern Portuguese coastline: Chemical approach by HPLC-DAD-ESI/MS and UPLC-ESI-QTOF/MS. Algal Res. 2018, 29, 113-120. [CrossRef]

77. Rydberg, J.; Musikas, C.; Choppin, G.R. (Eds.) Principles and Practices of Solvent Extraction; M. Dekker: New York, NY, USA, 1992.

78. Lee, J.-H.; Ko, J.-Y.; Oh, J.-Y.; Kim, C.-Y.; Lee, H.-J.; Kim, J.; Jeon, Y.-J. Preparative isolation and purification of phlorotannins from Ecklonia cava using centrifugal partition chromatography by one-step. Food Chem. 2014, 158, 433-437. [CrossRef] [PubMed]

79. Tierney, M.S.; Smyth, T.; Rai, D.; Soler-Vila, A.; Croft, A.; Brunton, N. Enrichment of polyphenol contents and antioxidant activities of Irish brown macroalgae using food-friendly techniques based on polarity and molecular size. Food Chem. 2013, 139, 753-761. [CrossRef] [PubMed]

80. Li, Y.; Qian, Z.-J.; Ryu, B.; Lee, S.-H.; Kim, M.-M.; Kim, S.-K. Chemical components and its antioxidant properties in vitro: An edible marine brown alga, Ecklonia cava. Bioorg. Med. Chem. 2009, 17, 1963-1973. [CrossRef]

81. Smith, E.L.; Abbott, A.P.; Ryder, K.S. Deep Eutectic Solvents (DESs) and Their Applications. Chem. Rev. 2014, 114, 11060-11082. [CrossRef] [PubMed] 
82. Radošević, K.; Ćurko, N.; Srček, V.G.; Bubalo, M.C.; Tomašević, M.; Ganić, K.K.; Redovniković, I.R. Natural deep eutectic solvents as beneficial extractants for enhancement of plant extracts bioactivity. LWT Food Sci. Technol. 2016, 73, 45-51. [CrossRef]

83. Nam, M.W.; Zhao, J.; Lee, M.S.; Jeong, J.H.; Lee, J. Enhanced extraction of bioactive natural products using tailor-made deep eutectic solvents: Application to flavonoid extraction from Flos sophorae. Green Chem. 2015, 17, 1718-1727. [CrossRef]

84. Obluchinskaya, E.D.; Daurtseva, A.V.; Pozharitskaya, O.N.; Flisyuk, E.V.; Shikov, A.N. Natural Deep Eutectic Solvents as Alternatives for Extracting Phlorotannins from Brown Algae. Pharm. Chem. J. 2019, 53, 243-247. [CrossRef]

85. Gall, E.A.; Lelchat, F.; Hupel, M.; Jégou, C.; Stiger-Pouvreau, V. Extraction and Purification of Phlo-rotannins from Brown Algae. In Natural Products from Marine Algae; Stengel, D.B., Connan, S., Eds.; Springer: New York, NY, USA, 2015; Volume 1308, pp. 131-144. ISBN 978-1-4939-2683-1.

86. Erpel, F.; Mateos, R.; Pérez-Jiménez, J.; Pérez-Correa, J.R. Phlorotannins: From isolation and structural characterization, to the evaluation of their antidiabetic and anticancer potential. Food Res. Int. 2020, 137, 109589. [CrossRef] [PubMed]

87. Kadam, S.U.; Tiwari, B.K.; Smyth, T.; O'Donnell, C.P. Optimization of ultrasound assisted extraction of bioactive components from brown seaweed Ascophyllum nodosum using response surface methodology. Ultrason. Sonochem. 2015, 23, 308-316. [CrossRef] [PubMed]

88. Tierney, M.S.; Soler-Vila, A.; Rai, D.K.; Croft, A.K.; Brunton, N.P.; Smyth, T.J. UPLC-MS profiling of low molecular weight phlorotannin polymers in Ascophyllum nodosum, Pelvetia canaliculata and Fucus spiralis. Metabolomics 2014, 10, 524-535. [CrossRef]

89. Singleton, V.L.; Rossi, J.A. Colorimetry of Total Phenolics with Phosphomolybdic-Phosphotungstic Acid Reagents. Am. J. Enol. Vitic. 1965, 16, 144-158.

90. Connan, S.; Goulard, F.; Stiger, V.; Deslandes, E.; Gall, E.A. Interspecific and temporal variation in phlorotannin levels in an assemblage of brown algae. Bot. Mar. 2004, 47, 57. [CrossRef]

91. Breton, F.; Cérantola, S.; Gall, E.A. Distribution and radical scavenging activity of phenols in Ascophyllum nodosum (Phaeophyceae). J. Exp. Mar. Biol. Ecol. 2011, 399, 167-172. [CrossRef]

92. Lamuela-Raventós, R.M. Folin-Ciocalteu method for the measurement of total phenolic content and antioxidant capacity. In Measurement of Antioxidant Activity E Capacity; Wiley: Chichester, UK, 2017; pp. 107-115.

93. Mariotti-Celis, M.S.; Martínez-Cifuentes, M.; Huamán-Castilla, N.; Pedreschi, F.; Iglesias-Rebolledo, N.; Pérez-Correa, J.R. Impact of an integrated process of hot pressurised liquid extraction-macroporous resin purification over the polyphenols, hydroxymethylfurfural and reducing sugars content of Vitis vinifera 'Carménère' pomace extracts. Int. J. Food Sci. Technol. 2018, 53, 1072-1078. [CrossRef]

94. Huaman-Castilla, N.L.; Martínez-Cifuentes, M.; Camilo, C.; Pedreschi, F.; Mariotti-Celis, M.; Pérez-Correa, J.R. The Impact of Temperature and Ethanol Concentration on the Global Recovery of Specific Polyphenols in an Integrated HPLE/RP Process on Carménère Pomace Extracts. Molecules 2019, 24, 3145. [CrossRef]

95. Mariotti-Celis, M.S.; Martínez-Cifuentes, M.; Huamán-Castilla, N.; Vargas-González, M.; Pedreschi, F.; Pérez-Correa, J.R. The Antioxidant and Safety Properties of Spent Coffee Ground Extracts Impacted by the Combined Hot Pressurized Liquid ExtractionResin Purification Process. Molecules 2017, 23, 21. [CrossRef]

96. Huamán-Castilla, N.L.; Mariotti-Celis, M.S.; Martínez-Cifuentes, M.; Pérez-Correa, J.R. Glycerol as Alternative Co-Solvent for Water Extraction of Polyphenols from Carménère Pomace: Hot Pressurized Liquid Extraction and Computational Chemistry Calculations. Biomolecules 2020, 10, 474. [CrossRef] [PubMed]

97. Kong, C.-S.; Kim, J.-A.; Yoon, N.-Y.; Kim, S.-K. Induction of apoptosis by phloroglucinol derivative from Ecklonia Cava in MCF-7 human breast cancer cells. Food Chem. Toxicol. 2009, 47, 1653-1658. [CrossRef] [PubMed]

98. Yang, Y.-I.; Ahn, J.-H.; Choi, Y.S.; Choi, J.-H. Brown algae phlorotannins enhance the tumoricidal effect of cisplatin and ameliorate cisplatin nephrotoxicity. Gynecol. Oncol. 2015, 136, 355-364. [CrossRef] [PubMed]

99. Shakibaei, M.; John, T.; Seifarth, C.; Mobasheri, A. Resveratrol Inhibits IL-1beta-Induced Stimulation of Caspase-3 and Cleavage of PARP in Human Articular Chondrocytes in Vitro. Ann. N. Y. Acad. Sci. 2007, 1095, 554-563. [CrossRef]

100. Perron, N.R.; Brumaghim, J.L. A Review of the Antioxidant Mechanisms of Polyphenol Compounds Related to Iron Binding. Cell Biochem. Biophys. 2009, 53, 75-100. [CrossRef] [PubMed]

101. Kim, H.-S.; Quon, M.; Kim, J.-A. New insights into the mechanisms of polyphenols beyond antioxidant properties; lessons from the green tea polyphenol, epigallocatechin 3-gallate. Redox Biol. 2014, 2, 187-195. [CrossRef] [PubMed]

102. Le, Q.-T.; Li, Y.; Qian, Z.-J.; Kim, M.-M.; Kim, S.-K. Inhibitory effects of polyphenols isolated from marine alga Ecklonia cava on histamine release. Process. Biochem. 2009, 44, 168-176. [CrossRef]

103. Venkatesan, J.; Keekan, K.K.; Anil, S.; Bhatnagar, I.; Kim, S.-K. Phlorotannins. In Encyclopedia of Food Chemistry; Elsevier: Amsterdam, The Netherlands, 2019.

104. Lim, S.D.; Sun, C.; Lambeth, J.D.; Marshall, F.; Amin, M.; Chung, L.; Petros, J.A.; Arnold, R.S. Increased Nox1 and hydrogen peroxide in prostate cancer. Prostate 2005, 62, 200-207. [CrossRef]

105. Heo, S.-J.; Hwang, J.-Y.; Choi, J.-I.; Lee, S.-H.; Park, P.-J.; Kang, D.-H.; Oh, C.; Kim, D.-W.; Han, J.-S.; Jeon, Y.-J.; et al. Protective effect of diphlorethohydroxycarmalol isolated from Ishige okamurae against high glucose-induced-oxidative stress in human umbilical vein endothelial cells. Food Chem. Toxicol. 2010, 48, 1448-1454. [CrossRef]

106. Sharma, O.P.; Bhat, T.K. DPPH antioxidant assay revisited. Food Chem. 2009, 113, 1202-1205. [CrossRef]

107. Ahn, M.-J.; Yoon, K.-D.; Min, S.-Y.; Lee, J.S.; Kim, J.H.; Kim, T.G.; Kim, S.H.; Kim, N.-G.; Huh, H.; Kim, J. Inhibition of HIV-1 Reverse Transcriptase and Protease by Phlorotannins from the Brown Alga Ecklonia cava. Biol. Pharm. Bull. 2004, 27, 544-547. [CrossRef] 
108. Quéguineur, B.; Goya, L.; Ramos, S.; Martín, M.A.; Mateos, R.; Bravo, L. Phloroglucinol: Antioxidant properties and effects on cellular oxidative markers in human HepG2 cell line. Food Chem. Toxicol. 2012, 50, 2886-2893. [CrossRef] [PubMed]

109. Yotsu-Yamashita, M.; Kondo, S.; Segawa, S.; Lin, Y.-C.; Toyohara, H.; Ito, H.; Konoki, K.; Cho, Y.; Uchida, T. Isolation and Structural Determination of Two Novel Phlorotannins from the Brown Alga Ecklonia kurome Okamura, and Their Radical Scavenging Activities. Mar. Drugs 2013, 11, 165-183. [CrossRef]

110. Audibert, L.; Fauchon, M.; Blanc, N.; Hauchard, D.; Ar Gall, E. Phenolic compounds in the brown seaweed Ascophyllum nodosum: Distribution and radical-scavenging activities. Phytochem. Anal. 2010, 21, 399-405. [CrossRef]

111. Lee, S.-H.; Park, M.-H.; Kang, S.-M.; Ko, S.-C.; Kang, M.-C.; Cho, S.; Park, P.-J.; Jeon, B.-T.; Kim, S.-K.; Han, J.-S.; et al. Dieckol Isolated from Ecklonia cava Protects against High-Glucose Induced Damage to Rat Insulinoma Cells by Reducing Oxidative Stress and Apoptosis. Biosci. Biotechnol. Biochem. 2012, 76, 1445-1451. [CrossRef] [PubMed]

112. Appendino, G.; Ottino, M.; Marquez, N.; Bianchi, F.; Giana, A.; Ballero, M.; Sterner, O.; Fiebich, B.L.; Munoz, E. Arzanol, an Anti-inflammatory and Anti-HIV-1 Phloroglucinol $\alpha$-Pyrone from Helichrysum italicum ssp. microphyllum. J. Nat. Prod. 2007, 70, 608-612. [CrossRef] [PubMed]

113. Nakane, H.; Arisawa, M.; Fujita, A.; Koshimura, S.; Ono, K. Inhibition of HIV-reverse transcriptase activity by some phloroglucinol derivatives. FEBS Lett. 1991, 286, 83-85. [CrossRef]

114. Chauthe, S.K.; Bharate, S.B.; Sabde, S.; Mitra, D.; Bhutani, K.K.; Singh, I.P. Biomimetic synthesis and anti-HIV activity of dimeric phloroglucinols. Bioorg. Med. Chem. 2010, 18, 2029-2036. [CrossRef] [PubMed]

115. Sanna, C.; Scognamiglio, M.; Fiorentino, A.; Corona, A.; Graziani, V.; Caredda, A.; Cortis, P.; Montisci, M.; Ceresola, E.R.; Canducci, F; et al. Prenylated phloroglucinols from Hypericum scruglii, an endemic species of Sardinia (Italy), as new dual HIV-1 inhibitors effective on HIV-1 replication. PLoS ONE 2018, 13, e0195168. [CrossRef] [PubMed]

116. Cuong, D.X.; Boi, V.N.; Van, T.T.T.; Hau, L.N. Effect of storage time on phlorotannin content and antioxidant activity of six Sargassum species from Nhatrang Bay, Vietnam. Environ. Boil. Fishes 2016, 28, 567-572. [CrossRef]

117. Charoensiddhi, S.; Franco, C.; Su, P.; Zhang, W. Improved antioxidant activities of brown seaweed Ecklonia radiata extracts prepared by microwave-assisted enzymatic extraction. Environ. Boil. Fishes 2015, 27, 2049-2058. [CrossRef]

118. Herrlich, P.; Blattner, C.; Knebel, A.; Bender, K.; Rahmsdorf, H.J.; Rahmsdorf, H.J. Nuclear and Non-Nuclear Targets of Genotoxic Agents in the Induction of Gene Expression. Shared Principlesin Yeast, Rodents, Man and Plants. Biol. Chem. 1997, 378, 1299. [CrossRef]

119. Matsumura, Y.; Ananthaswamy, H.N. Toxic effects of ultraviolet radiation on the skin. Toxicol. Appl. Pharmacol. 2004, 195, 298-308. [CrossRef] [PubMed]

120. Yin, L.; Morita, A.; Tsuji, T. Alterations of extracellular matrix induced by tobacco smoke extract. Arch. Dermatol. Res. 2000, 292, 188-194. [CrossRef] [PubMed]

121. Kondo, S. The roles of cytokines in photoaging. J. Dermatol. Sci. 2000, 23, S30-S36. [CrossRef]

122. Pallela, R.; Na-Young, Y.; Kim, S.-K. Anti-photoaging and Photoprotective Compounds Derived from Marine Organisms. Mar. Drugs 2010, 8, 1189-1202. [CrossRef]

123. McCullough, J.L.; Kelly, K.M. Prevention and treatment of skin aging. In Aging Interventions and Therapies; World Scientific Publishing Company: Singapore, 2006; pp. 323-331.

124. Shannon, E.; Abu-Ghannam, N. Antibacterial Derivatives of Marine Algae: An Overview of Pharmacological Mechanisms and Applications. Mar. Drugs 2016, 14, 81. [CrossRef]

125. Kang, N.-J.; Han, S.-C.; Kang, G.-J.; Koo, D.-H.; Koh, Y.-S.; Hyun, J.-W.; Lee, N.-H.; Ko, M.-H.; Kang, H.-K.; Yoo, E.-S. Diphlorethohydroxycarmalol Inhibits Interleukin-6 Production by Regulating NF-kB, STAT5 and SOCS1 in Lipopolysaccharide-Stimulated RAW264.7 Cells. Mar. Drugs 2015, 13, 2141-2157. [CrossRef] [PubMed]

126. Karadeniz, F.; Ahn, B.-N.; Kim, J.-A.; Seo, Y.; Jang, M.-S.; Nam, K.-H.; Kim, M.; Lee, S.-H.; Kong, C.-S. Phlorotannins suppress adipogenesis in pre-adipocytes while enhancing osteoblastogenesis in pre-osteoblasts. Arch. Pharm. Res. 2015, 38, 2172-2182. [CrossRef]

127. Park, M.-H.; Heo, S.-J.; Kim, K.-N.; Ahn, G.; Park, P.-J.; Moon, S.-H.; Jeon, B.-T.; Lee, S.-H. 6,6'-Bieckol protects insulinoma cells against high glucose-induced glucotoxicity by reducing oxidative stress and apoptosis. Fitoterapia 2015, 106, 135-140. [CrossRef] [PubMed]

128. Kwon, H.-J.; Ryu, Y.B.; Kim, Y.-M.; Song, N.; Kim, C.Y.; Rho, M.-C.; Jeong, J.-H.; Cho, K.-O.; Lee, W.S.; Park, S.-J. In vitro antiviral activity of phlorotannins isolated from Ecklonia cava against porcine epidemic diarrhea coronavirus infection and hemagglutination. Bioorganic Med. Chem. 2013, 21, 4706-4713. [CrossRef] [PubMed]

129. Kang, I.-J.; Jang, B.G.; In, S.; Choi, B.; Kim, M.; Kim, M.-J. Phlorotannin-rich Ecklonia cava reduces the production of beta-amyloid by modulating alpha- and gamma-secretase expression and activity. NeuroToxicology 2013, 34, 16-24. [CrossRef] [PubMed]

130. Ryu, B.; Li, Y.; Qian, Z.-J.; Kim, M.-M.; Kim, S.-K. Differentiation of human osteosarcoma cells by isolated phlorotannins is subtly linked to COX-2, iNOS, MMPs, and MAPK signaling: Implication for chronic articular disease. Chem. Interact. 2009, 179, 192-201. [CrossRef] [PubMed]

131. Ahn, G.; Amagai, Y.; Matsuda, A.; Kang, S.-M.; Lee, W.; Jung, K.; Oida, K.; Jang, H.; Ishizaka, S.; Matsuda, K.; et al. Dieckol, a phlorotannin of Ecklonia cava, suppresses IgE-mediated mast cell activation and passive cutaneous anaphylactic reaction. Exp. Dermatol. 2015, 24, 968-970. [CrossRef] [PubMed]

132. Sugiura, Y.; Matsuda, K.; Yamada, Y.; Nishikawa, M.; Shioya, K.; Katsuzaki, H.; Imai, K.; Amano, H. Isolation of a New AntiAllergic Phlorotannin, Phlorofucofuroeckol-B, from an Edible Brown Alga, Eisenia arborea. Biosci. Biotechnol. Biochem. 2006, 70, 2807-2811. [CrossRef] [PubMed] 
133. Sugiura, Y.; Matsuda, K.; Yamada, Y.; Nishikawa, M.; Shioya, K.; Katsuzaki, H.; Imai, K.; Amano, H. Anti-Allergic Phlorotannins from the Edible Brown Alga, Eisenia Arborea. Food Sci. Technol. Res. 2007, 13, 54-60. [CrossRef]

134. Cassani, L.; Gomez-Zavaglia, A.; Jimenez-Lopez, C.; Lourenço-Lopes, C.; Prieto, M.A.; Simal-Gandara, J. Seaweed-based natural ingredients: Stability of phlorotannins during extraction, storage, passage through the gastrointestinal tract and potential incorporation into functional foods. Food Res. Int. 2020, 137, 109676. [CrossRef] [PubMed]

135. Corona, G.; Ji, Y.; Anegboonlap, P.; Hotchkiss, S.; Gill, C.; Yaqoob, P.; Spencer, J.P.E.; Rowland, I. Gastrointestinal modifications and bioavailability of brown seaweed phlorotannins and effects on inflammatory markers. Br. J. Nutr. 2016, 115, 1240-1253. [CrossRef]

136. Etheridge, M.L.; Campbell, S.; Erdman, A.G.; Haynes, C.; Wolf, S.M.; McCullough, J. The big picture on nanomedicine: The state of investigational and approved nanomedicine products. Nanomed. Nanotechnol. Biol. Med. 2013, 9, 1-14. [CrossRef] [PubMed]

137. Reis, C.; Neufeld, R.J.; Ribeiro, A.; Veiga, F. Nanoencapsulation I. Methods for preparation of drug-loaded polymeric nanoparticles. Nanomed. Nanotechnol. Biol. Med. 2006, 2, 8-21. [CrossRef]

138. Merisko-Liversidge, E.; Liversidge, G.G. Nanosizing for oral and parenteral drug delivery: A perspective on formulating poorly-water soluble compounds using wet media milling technology. Adv. Drug Deliv. Rev. 2011, 63, 427-440. [CrossRef] [PubMed]

139. Shibata, T.; Ishimaru, K.; Kawaguchi, S.; Yoshikawa, H.; Hama, Y. Antioxidant activities of phlorotannins isolated from Japanese Laminariaceae. Environ. Boil. Fishes 2008, 20, 705-711. [CrossRef]

140. Kim, M.; Kim, G. Electrospun PCL/phlorotannin nanofibres for tissue engineering: Physical properties and cellular activities. Carbohydr. Polym. 2012, 90, 592-601. [CrossRef] [PubMed]

141. Je, H.J.; Kim, E.S.; Lee, J.-S.; Lee, H.G. Release Properties and Cellular Uptake in Caco-2 Cells of Size-Controlled Chitosan Nanoparticles. J. Agric. Food Chem. 2017, 65, 10899-10906. [CrossRef] [PubMed]

142. Gupta, B.S.; Chen, B.-R.; Lee, M.-J. Solvation consequences of polymer PVP with biological buffers MES, MOPS, and MOPSO in aqueous solutions. J. Chem. Thermodyn. 2015, 91, 62-72. [CrossRef] 